\title{
Heat load assessment in Central European cities using an urban climate model and observational monitoring data
}

\author{
Anita Bokwa ${ }^{\mathrm{a}, *}$, Jan Geletič ${ }^{\mathrm{b}, c}$, Michal Lehnert ${ }^{\mathrm{d}}$, Maja Žuvela-Aloise ${ }^{\mathrm{e}}$, Brigitta Hollósi ${ }^{\mathrm{e}}$, \\ Tamás Gál ${ }^{\mathrm{f}}$, Nóra Skarbit ${ }^{\mathrm{f}}$, Petr Dobrovolný ${ }^{\mathrm{c}, \mathrm{g}}$, Monika J. Hajto ${ }^{\mathrm{h}, \mathrm{a}}$, Rafał Kielar ${ }^{\mathrm{h}}$, \\ Jakub P. Walawender ${ }^{\mathrm{h}, * *}$, Pavel Št'astný ${ }^{\mathrm{i}}$, Juraj Holec ${ }^{\mathrm{i}, \mathrm{j}}$, Katarzyna Ostapowicz ${ }^{\mathrm{a}}$, \\ Jarmila Burianovág, Marcel Garaj ${ }^{\mathrm{i}, \mathrm{k}}$ \\ a Jagiellonian University, Institute of Geography and Spatial Management, 7 Gronostajowa St., 30-387 Kraków, Poland \\ ${ }^{\mathrm{b}}$ Institute of Computer Science of the Czech Academy of Sciences, Department of Complex Systems, Pod Vodárenskou věži 271/2, 182 07 \\ Prague, Czech Republic \\ ${ }^{\mathrm{c}}$ Global Change Research Institute of the Czech Academy of Sciences, Bělidla St. 986/4a, 60300 Brno, Czech Republic \\ d Palacký University in Olomouc, Department of Geography, Faculty of Science, 17. Listopadu St. 12, 77146 Olomouc, Czech Republic \\ e Zentralanstalt für Meteorologie und Geodynamik (ZAMG), Division Data, Methods, Modeling, Section Model Applications, Hohe Warte 38 , 1190 Wien, \\ Austria \\ ${ }^{\mathrm{f}}$ University of Szeged, 13 Dugonics ter St., Szeged H-6720, Hungary \\ ${ }^{g}$ Masaryk University Brno, Faculty of Science, Department of Geography, Kotlářská 2, 61137 Brno, Czech Republic \\ ${ }^{\mathrm{h}}$ Institute of Meteorology and Water Management - National Research Institute, 14 Borowego St., 30-215 Kraków, Poland \\ i Slovak Hydrometeorological Institute, Jeséniova St. 17, 83315 Bratislava, Slovakia \\ j Comenius University in Bratislava, Faculty of Natural Sciences, Department of Physical Geography and Geoecology, Mlynská dolina, Ilkovičova St. 6, \\ 84215 Bratislava, Slovakia \\ k Slovak Academy of Sciences, Institute of Hydrology, Dúbravská cesta 9, 84104 Bratislava, Slovakia
}

\section{A R T I C L E I N F O}

\section{Article history:}

Received 6 July 2018

Revised 8 July 2019

Accepted 11 July 2019

Available online 11 July 2019

\section{Keywords:}

Heatwave

Thermal comfort

Urban climate

Air temperature

MUKLIMO_3

\begin{abstract}
A B S T R A C T
Diurnal variability of spatial pattern of air temperature was studied in five cities in Central Europe: Bratislava (Slovakia), Brno (Czech Republic), Kraków (Poland), Szeged (Hungary) and Vienna (Austria), during one of the heat waves in 2015 (4-14 August), with the application of micro-climate model MUKLIMO_3. 8th August was chosen to study in detail the urban heat load at 10.00, 16.00, 22.00 and 4.00 CEST. Local Climate Zones concept was used to supply data for the model and for the interpretation of the results obtained. Model outcomes were validated with measurement data from 86 points belonging to the networks which operate in the cities studied. The results obtained show that among urban LCZ, the highest heat load was observed for LCZ 2 and 3 from 16.00 to 4.00 , while at 10.00 there is no such clear pattern. Unlike forested areas, open green areas can contribute to the generation of high air temperature: $>35^{\circ} \mathrm{C}$ during day time and $>30^{\circ} \mathrm{C}$ during night time. Important factors controlling the intra-zonal and inter-zonal variability of air temperature in particular LCZs are the local environmental conditions. During the day time, diversified relief in the area of the city and its vicinities generates higher heat load in the valleys' floors than in areas located above, both in rural and urban areas. The same landforms experience lower heat load during the night time due to air temperature inversions effect.
\end{abstract}

(c) 2019 Elsevier B.V. All rights reserved.

\footnotetext{
* Corresponding author.

E-mail addresses: anita.bokwa@uj.edu.pl (A. Bokwa), geletic.jan@gmail.com (J. Geletič), michal.lehnert@gmail.com (M. Lehnert), maja.zuvela-aloise@zamg.ac.at (M. Žuvela-Aloise), brigitta.hollosi@zamg.ac.at (B. Hollósi), tgal@geo.u-szeged.hu (T. Gál), skarbitnora@gmail.com (N. Skarbit), dobro@sci.muni.cz (P. Dobrovolný), monika.hajto@imgw.pl (M.J. Hajto), rkielar@gmail.com (R. Kielar), contact@jakubwalawender.pl (J.P. Walawender), Pavel.Stastny@shmu.sk (P. Štastný), Juraj.Holec@shmu.sk (J. Holec), katarzyna.ostapowicz@uj.edu.pl (K. Ostapowicz), burianova@geogr.muni.cz (J. Burianová), garaj@uh.savba.sk (M. Garaj).

** Currently at: Deutscher Wetterdienst, Global Precipitation Climatology Centre, Frankfurter Straße 135, 63067 Offenbach, Germany
}

https://doi.org/10.1016/j.enbuild.2019.07.023

0378-7788/@ 2019 Elsevier B.V. All rights reserved.

\section{Introduction}

The urban climate is a phenomenon on a local scale but it has a direct and significant impact on $54 \%$ of the total global population living in cities [64], which is expected to grow further, by approximately $1.63 \%$ per year between 2020 and 2025 and by $1.44 \%$ per year between 2025 and 2030 [65]. The urban climate is a result of significant changes in radiative, thermal, moisture and aerodynamic characteristics. The major driver of these complex changes is the impact of the properties of urbanized areas (e.g. the size 


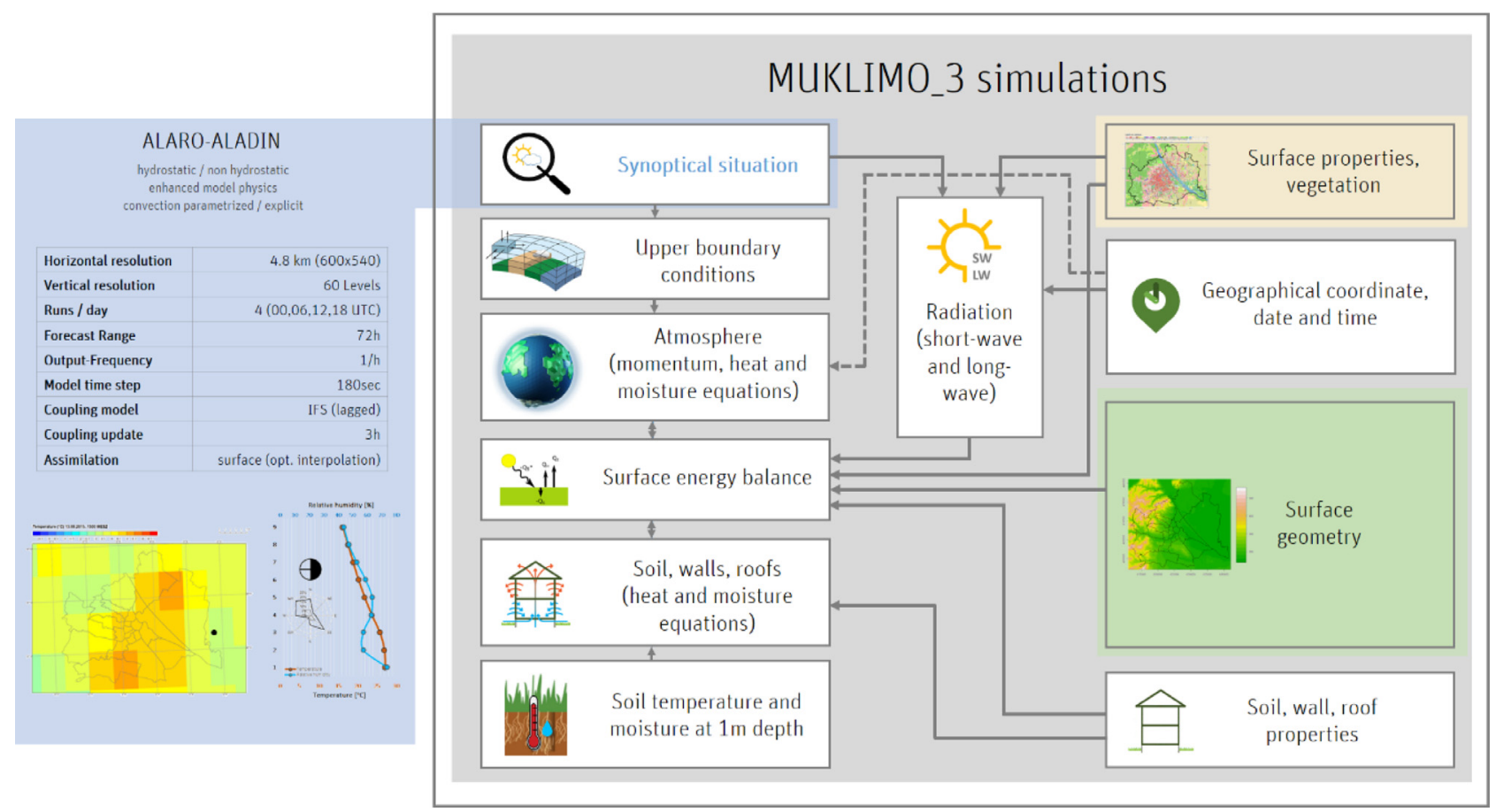

Fig. 1. Schematic structure of the MUKLIMO_3 model components, input data and coupling with the ALARO-ALADIN numerical weather prediction model.

a)
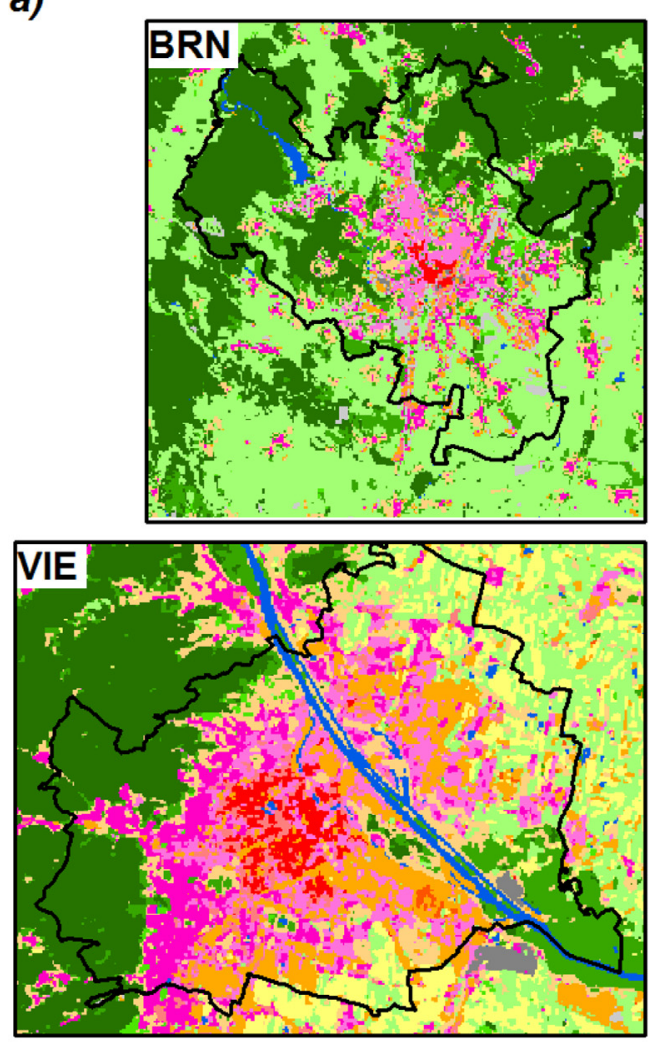

$\sqsubset \square$ city administrative borders

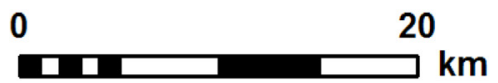

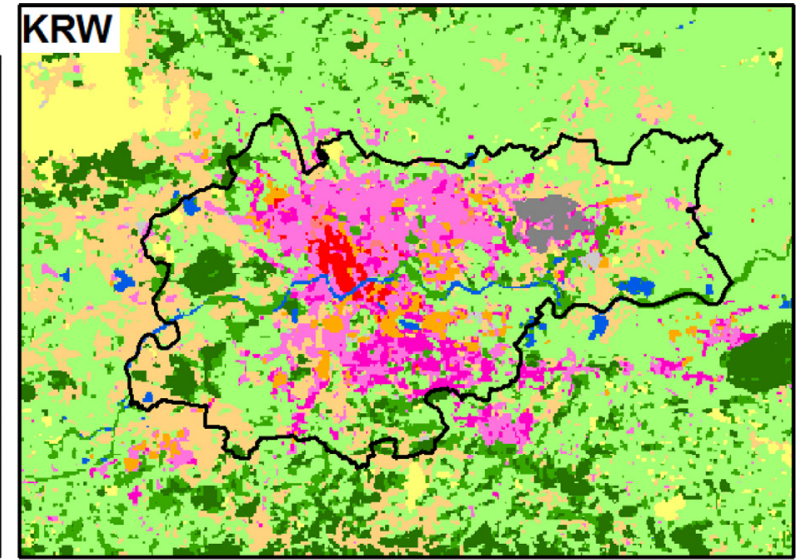

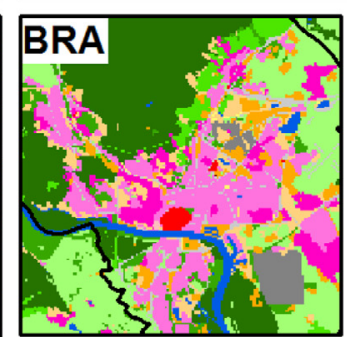

LCZ built types
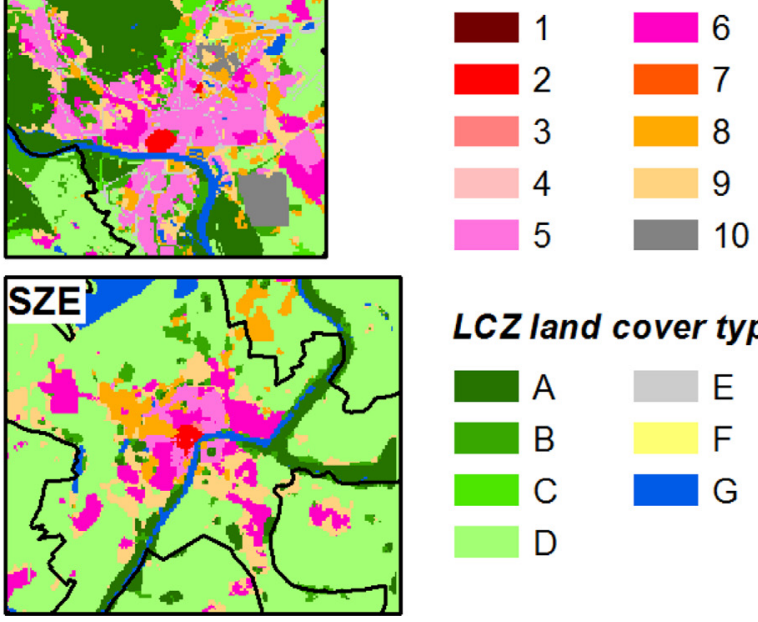

LCZ land cover types

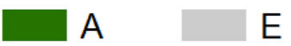

B $\quad F$

C $\square$

D

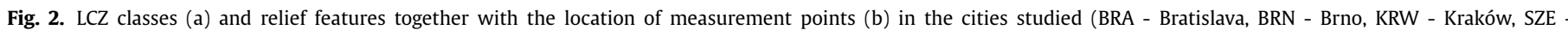
Szeged, VIE - Vienna); LCZ class description can be found in Appendix B. 
b)
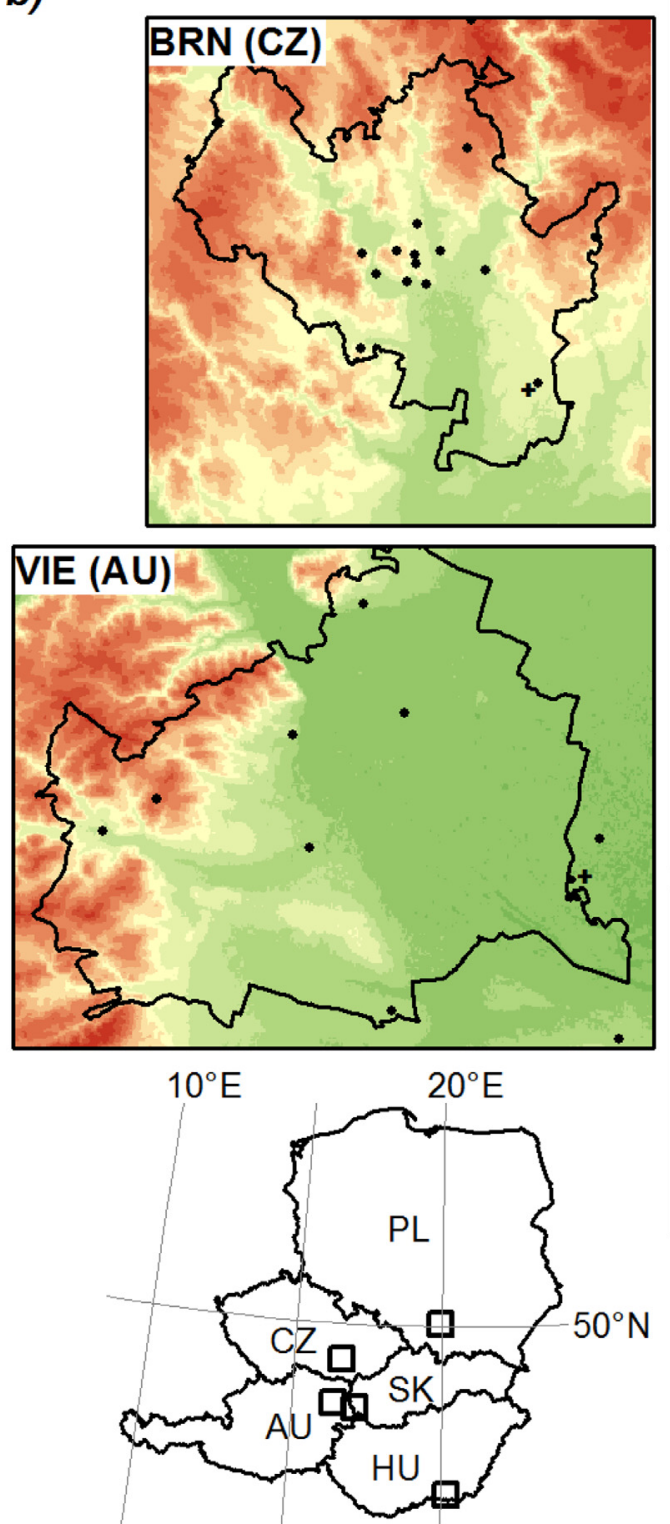
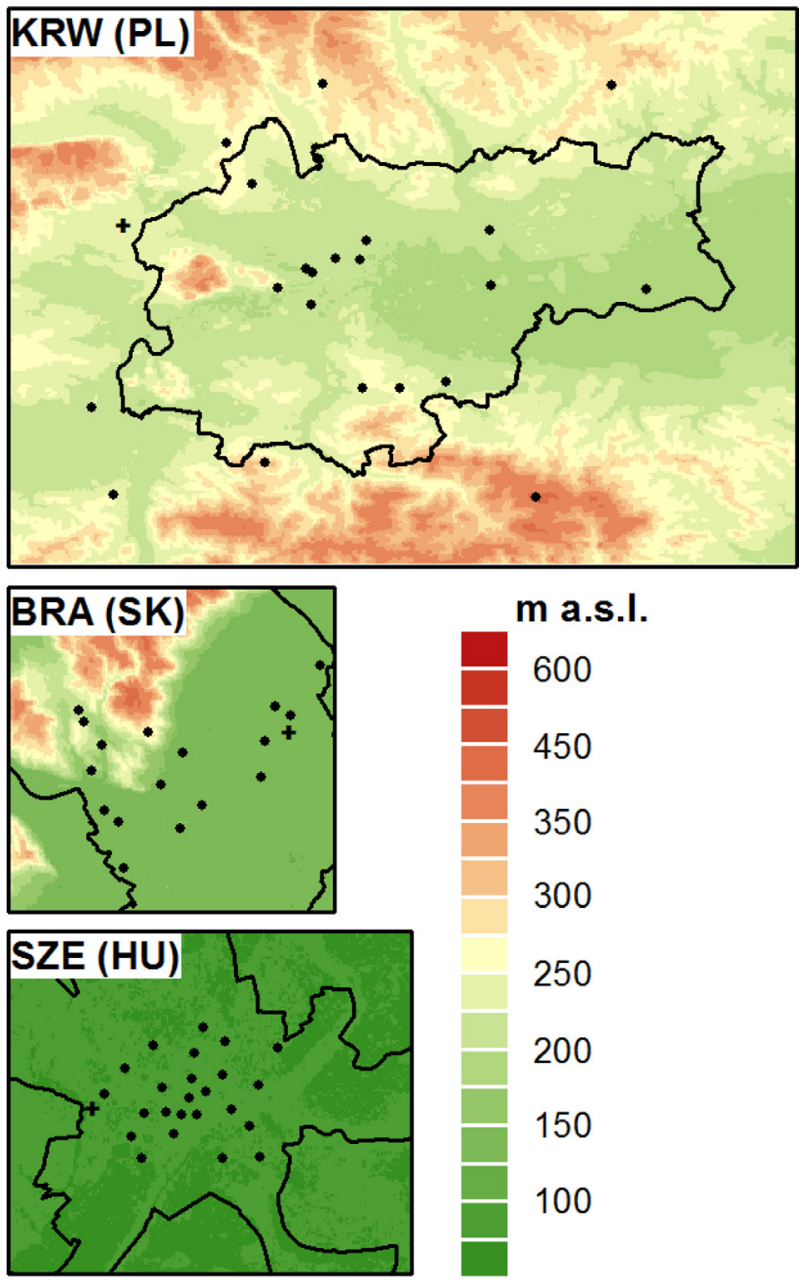

600

450

350

300

250

200

150

100

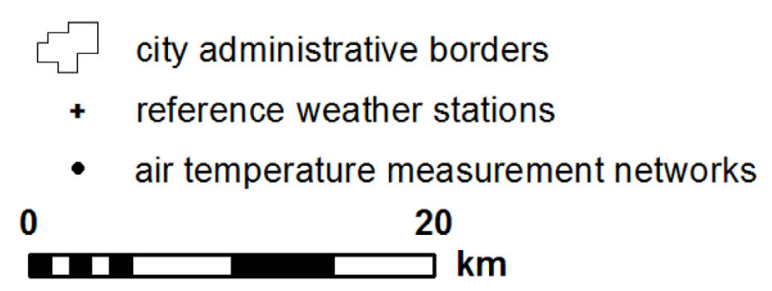

Fig. 2. Continued

and density of buildings, the share of green areas and water bodies, air pollution) on atmospheric processes (e.g. air flow, reflection of solar radiation due to surface albedo, precipitation origin), and that impact is additionally modified by local environmental conditions (e.g. relief which can contribute to the air temperature inversion occurrence, and vicinity of water bodies, which can change local wind field) (e.g. $[30,40]$ ). The present paper contributes to the studies concerning air temperature modifications in urban areas, during a summer time heat wave. The heat load in cities is expected to get intensified in the future as the global temperature increases, which becomes superimposed on air temperature modifications characteristic for urban areas, known as urban heat island (UHI) effect (e.g. $[24,30,40])$. Increased temperatures in urban areas during heat waves are of special importance and might be considered as extreme biothermal conditions resulting in far-reaching direct and indirect health effects (e.g. $[3,29,39,45,57]$ ). In addition, most recent studies concluded that during heat wave events, UHI effect is even more pronounced (e.g. $[4,24,36])$. In 2013, the European Commission published "An EU Strategy on adaptation to climate change" and recommended the preparation of national strategies, including urban areas [11]. Therefore, in order to plan and undertake the mitigation and adaptation actions in particular cities, it is necessary to recognize, among other elements, the magnitude and spatial extent of heat load in urban areas during heat wave events. With application of urban climate models supported by extensive on-site measurements it is possible to obtain the most complete information on UHI effect during a heat wave, in relation to both land use/land cover (LU/LC) and land form. For example, Meng et al. [37] showed the importance of high quality LU/LC data used in the WRF and UCM models in the prediction of UHI during a heat wave in Guangzhou, China. Li and Bou-Zeid [36] studied the case of a heat wave in Baltimore, USA, and showed that UHI intensity was increased owing to differences in the latent heat amount available in rural and urban areas. Similarly to Meng et al. [37], they used only two measurement points in model validation and recommended increasing that number in further studies. Gutiérrez et al. [23] analyzed a heat wave case for New York and used as many as 36 measurement points to validate the results obtained 
Table 1

Cities included in the study.

\begin{tabular}{lllll}
\hline City & Country & Area $\left[\mathrm{km}^{2}\right]$ & Altitude range $[\mathrm{m}$ a.s.l.] & Population (year) \\
\hline Bratislava & Slovakia & 368 & $126-450$ & $419,678(2015)$ \\
Brno & Czech Republic & 230 & $200-525$ & $377,000(2015)$ \\
Kraków & Poland & 327 & $145-459$ & $761,873(2014)$ \\
Szeged & Hungary & 281 & $46-143$ & $162,593(2015)$ \\
Vienna & Austria & 414 & $141-581$ & $1766,746(2014)$ \\
\hline
\end{tabular}

Explanations: area within the administrative border, altitude range within the domain taken for analyses

(extracted from DEM). Source of population data: http://ec.europa.eu/eurostat/web/cities/data/database.

with the WRF model. On that account, the aims of the present study are to: 1) define the diurnal variability of the spatial pattern of the air temperature in five Central European cities: Bratislava (Slovakia), Brno (Czech Republic), Kraków (Poland), Szeged (Hungary), and Vienna (Austria), during one of the summer heat waves of 2015, using micro-climate model MUKLIMO_3 which incorporates detailed information about relief, LU/LC and meteorological conditions, 2) validate MUKLIMO_3 model simulation results with data from automatic measurements networks, 3) define the areas most endangered by excessive heat load in the studied cities, in relation to the impact of particular factors included in the analyzes.

Considering that all the investigated cities (except Szeged) are located in areas with diversified relief, the interaction of microclimatic processes generated by both urban LU/LC and relief creates a complicated spatial structure of air temperature. The analysis of that structure makes it possible to estimate the role of both natural and anthropogenic factors in generating the excessive heat stress in urban areas.

\section{Study areas}

The analyzes were performed for five cities located in Central Europe (Table 1, Fig. 1). Various studies, previously completed for the selected cities, made it possible to achieve the recognition of their present urban climate features (e.g. [2,8$10,12,13,17,20,31,61,62,67])$. According to the Köppen-Geiger climate classification [28,44], Bratislava, Brno, Kraków and Vienna are located in the $\mathrm{Cfb}$ zone, while Szeged in the Cfa zone. Basic climatic data about the cities studied are shown in Appendix A.

Bratislava is located in southwestern Slovakia and it occupies both banks of the Danube river and the left bank of the Morava river. It is the country's largest city. The historical city center is located between the Danube and south-eastern slopes of the Carpathian mountain range, the Malé Karpaty Mts. City districts are primarily located in the lowermost areas. Complex orographic conditions in the Bratislava region generate the distinct and variable nature of the climate in the city and its surroundings. The Malé Karpaty Mts. especially affect overall air circulation and most of the climate characteristics.

Brno is situated in the south-eastern part of the Czech Republic. Its area is characterized by a basin position with complex terrain. Lower and flatter terrain is typical for the southern and eastern parts of the study area. There is a large water reservoir (with an area of approximately $2.6 \mathrm{~km}^{2}$ ) located on the north-western border of the built-up part. The study area lies in one of the warmest and the driest regions in the Czech Republic.

Kraków is located in southern Poland, in the valley of the Vistula river which passes from west to east. The historical city center is at the bottom of the Vistula river valley (about $200 \mathrm{~m}$ a.s.l.) and on a limestone tectonic horst (Wawel Hill), emerging from the river valley. The city area is surrounded by hills north, south, west, but not east. The urbanized areas can be found in the river valley with its terraces and in convex landforms to the north and south of the city centre [10].
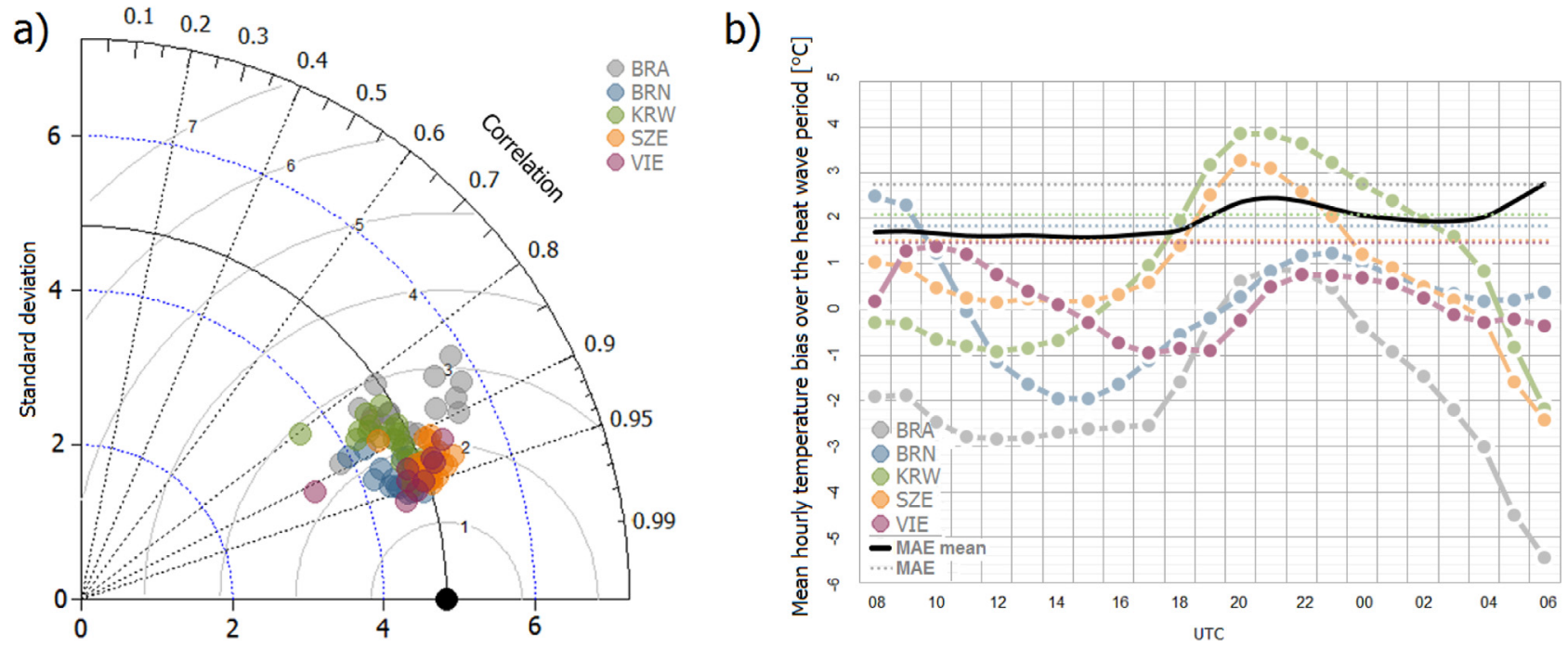

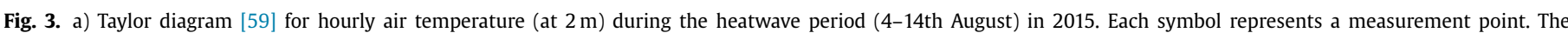

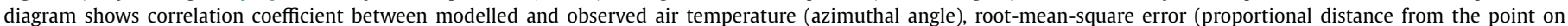

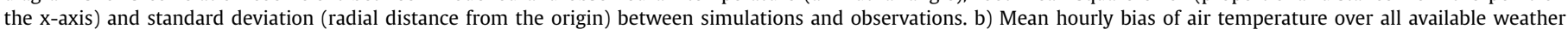
stations from each city during the whole heat wave period and the mean absolute error for the cities. 
10.00

CEST
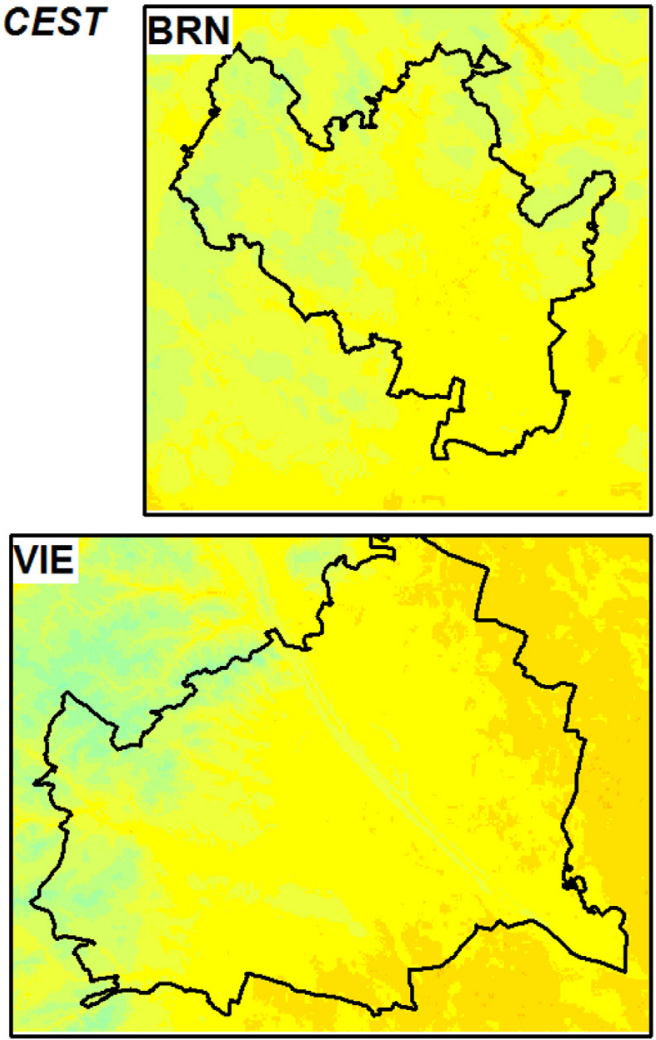

city administrative borders

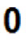

0

口
KRW

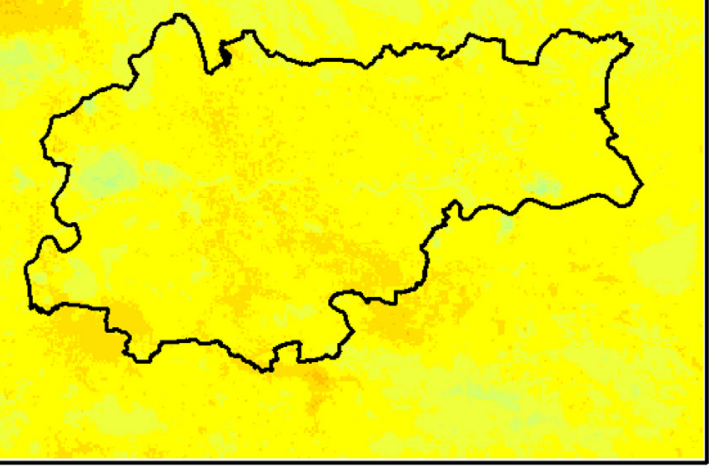

BRA Air temperature $\left({ }^{\circ} \mathrm{C}\right)$

35

30

25
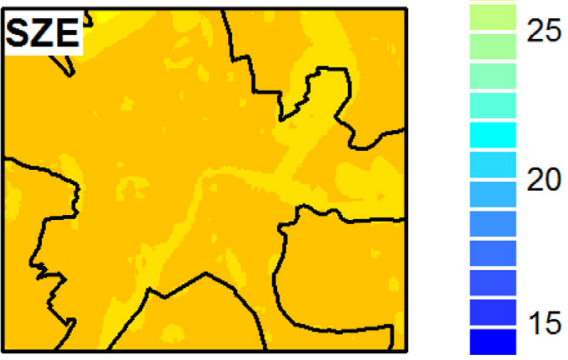

Fig. 4. Spatial distribution of modelled air temperature on 8th August at 10.00 in Bratislava (BRA), Brno (BRN), Kraków (KRW), Szeged (SZE) and Vienna (VIE).

Szeged is located in the Pannonian Plain in Central Europe. The urbanized area covers only about $30 \mathrm{~km}^{2}$ of the city. The Tisza River is the axis of the town and the city has a regular avenueboulevard structure. It is characterized by a densely built-up centre with historical buildings, blocks of flats in the northern part, and a large area of family houses and warehouses mostly in the western part [60].

Vienna is the capital city of Austria and the largest city used in this study. It is located at the easternmost extension of the Alps in a transition zone to the Pannonian Plain with the Danube River passing through the city. The urbanized area is characterized by the historical centre surrounded by a green belt, dense built-up areas in the inner districts, and low-density residential areas on the hillsides in the western part of the city and in the flat terrain in the south and east direction. Most of the industrial areas are located in the eastern and southern part of the city.

\section{Data and methods}

The study period is 4-14 August 2015, when the area of Central Europe experienced a heat wave. There are many definitions of a heat wave [47] and in the present paper the phenomenon is defined as a period of at least 3 days with maximum air temperature $\geq 30^{\circ} \mathrm{C}$. In all the cities studied, the maximum temperature was over $30^{\circ} \mathrm{C}$ each day of the study period chosen. Summer 2015 was one of the most extreme summer seasons in Europe in terms of thermal conditions and the high temperatures were caused by a combination of forced responses and internal atmospheric variability [14]. In the interpretation of the results obtained, a distinction is made between the spatial pattern of air temperature and UHI, as previous studies (e.g. [9]) showed that in urban areas located in concave land forms, UHI is often an element of a complex spatial pattern of air temperature. For example, in the case of air temperature inversion, UHI intensity is modified by the presence of cold and warm air strata in the valley. Further subsections describe methods used in the present study which consist of MUKLIMO_3 modeling and statistical analyzes while data used include LU/LC and meteorological data.

\subsection{MUKLIMO_3 model}

MUKLIMO_3 belongs to the group of computational fluid dynamics (CFD) models designed to simulate atmospheric flow fields in the presence of buildings [49,50,55]; e.g. ENVI-met [16], MITRAS [46], MIMO [15] or PALM-4U [42] can be mentioned as other examples. By coupling MUKLIMO_3 to regional numerical weather prediction models, statements on the behavior of key atmospheric variables considering the LU/LC characteristics on a local spatial (about $100-300 \mathrm{~m}$ ) resolution can be made. Furthermore, the thermo-dynamical version of the model with parameterization of unresolved buildings [52] shortwave and longwave radiation, balanced heat and moisture budgets in the soil [53] and a 
16.00

CEST
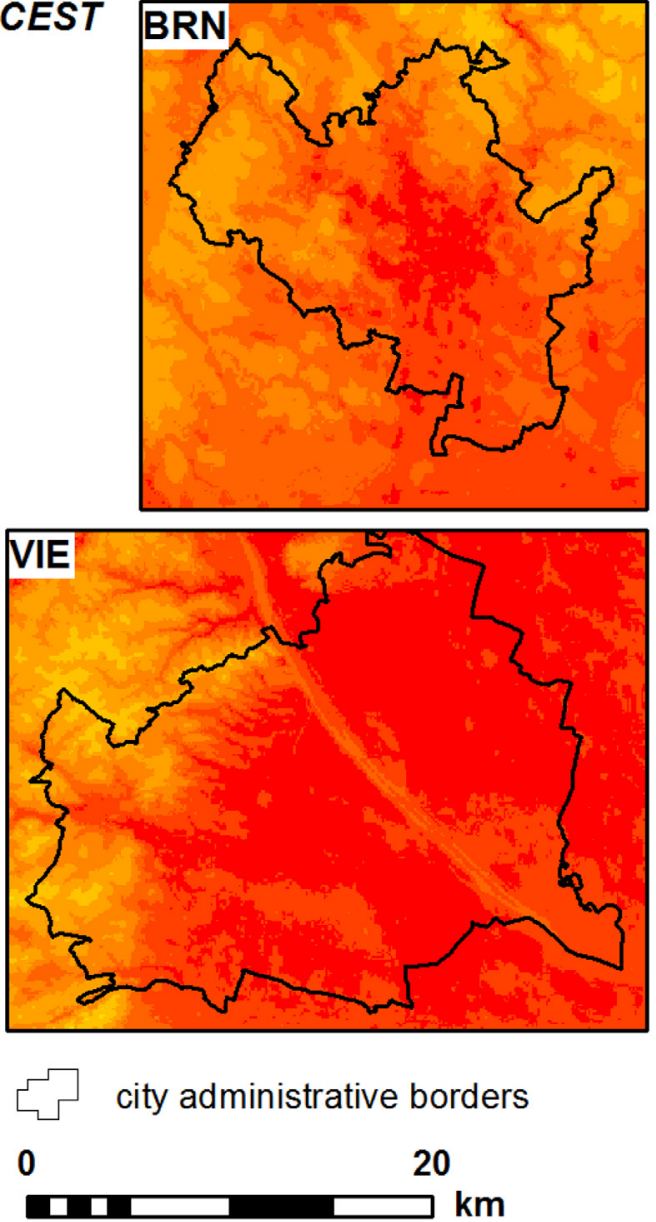

city administrative borders
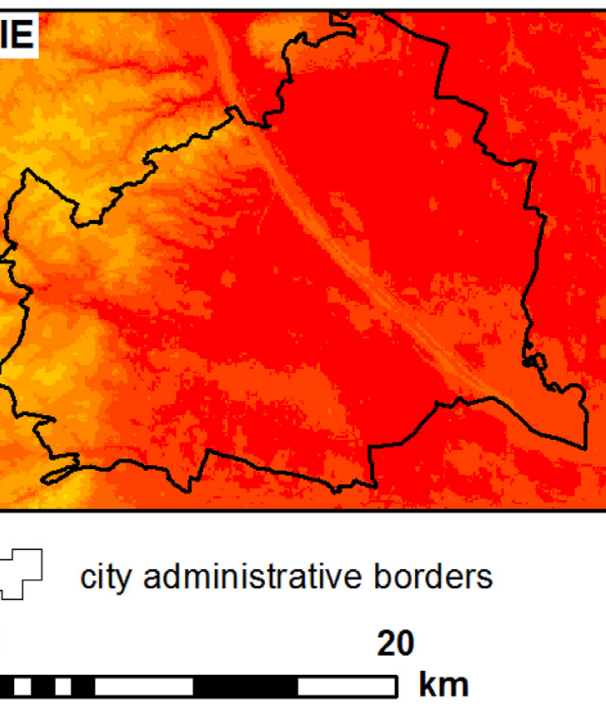

\section{KRW}
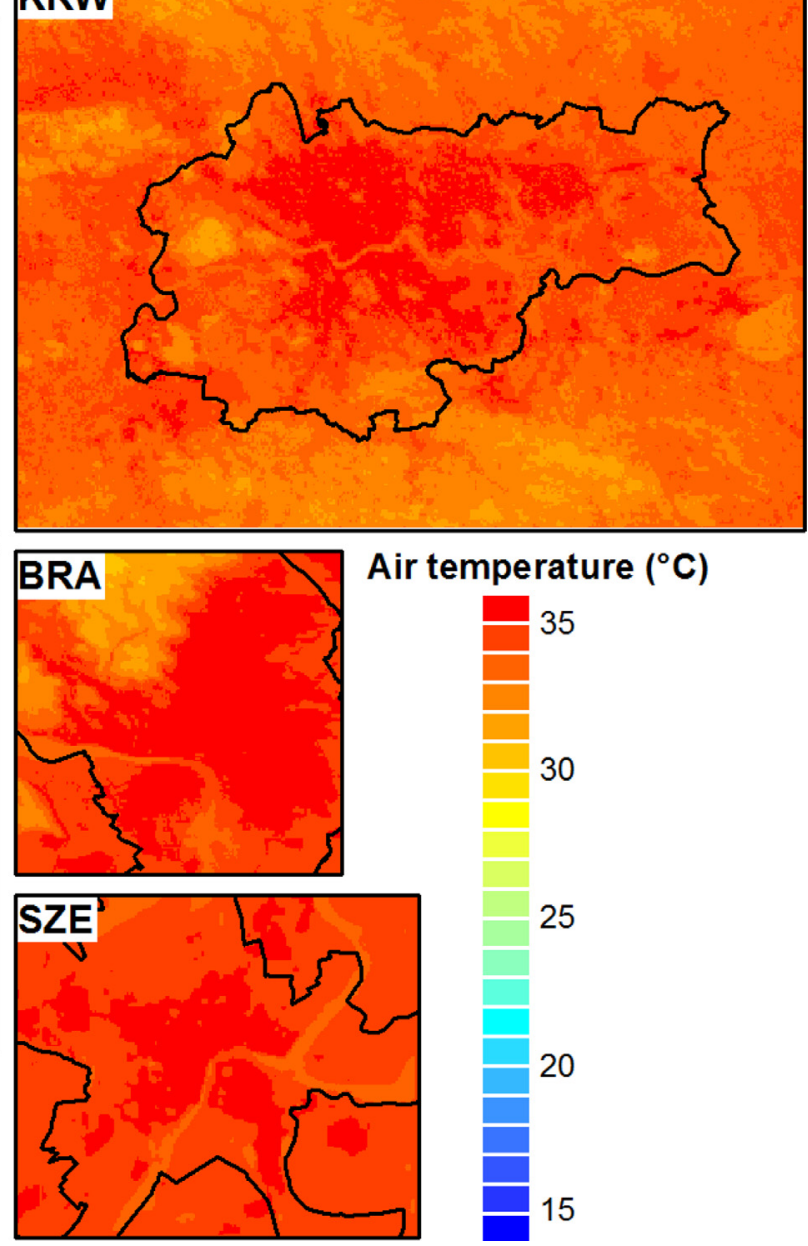

Air temperature $\left({ }^{\circ} \mathrm{C}\right)$

35

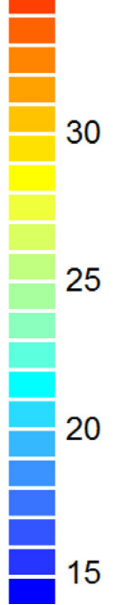

Fig. 5. Spatial distribution of modelled air temperature on 8th August at 16.00 in Bratislava (BRA), Brno (BRN), Kraków (KRW), Szeged (SZE) and Vienna (VIE).

vegetation model based on Siebert et al. [48] allows simulations of the urban environment on a larger spatial scale than other microscale models, including the effects of orography. The numerical treatment of unresolved built-up areas and trees includes heat, radiation, and water vapor balance at corresponding surfaces and adequate parametrization depending on the characteristics of the built-up and green areas [51, 52]. The numerical approach for the calculation of shortwave irradiances at the ground, the walls, and the roofs of buildings in an environment with unresolved built-up is described by Sievers and Früh [54]. The flow between buildings is parameterized through a porous media approach for unresolved buildings [22]. The unresolved buildings are characterized with the volume fraction (building area and height) and the wall area of the buildings within the grid cell. The model uses high-resolution orography and LU/LC distribution data. For each LU/LC class, a set of parameters is defined to describe LU/LC properties and urban structures: fraction of built area $\left(\gamma_{b}\right)$, mean building height $\left(h_{b}\right)$, wall area index $\left(\mathrm{w}_{\mathrm{b}}\right)$, fraction of pavement of the non-built area $(\mathrm{v})$, fraction of tree cover $\left(\sigma_{\mathrm{t}}\right)$ and fraction of low vegetation of the remaining surface $\left(\sigma_{c}\right)$, tree height $\left(h_{t}\right)$, and height of the low vegetation $\left(\mathrm{h}_{\mathrm{c}}\right)$. Fractions $\gamma_{\mathrm{b}}$ and $\sigma_{\mathrm{t}}$ are relative to the total grid cell area. Fraction $\mathrm{v}$ is relative to the area without buildings and trees and $\sigma_{c}$ is relative to the remaining surface (see Appendix B). The model does not include cloud processes, precipitation, horizontal runoff, or anthropogenic heat, but can simulate the daily cycle of temperature, relative humidity, and wind characteristics on a high resolution spatial scale. The model domain covering the urban and surrounding areas varies among cities. The simulations in this study were carried out on a horizontal resolution of $100 \mathrm{~m}$ and vertical resolution varying between 10 and $50 \mathrm{~m}$ with denser grid spacing near surface until about $1000 \mathrm{~m}$ vertical height. The boundary conditions are given by a time-varying $1 \mathrm{D}$ version of the MUKLIMO_3 model that simulates the daily cycle of temperature, wind, relative humidity, and energy fluxes at the reference station representative for atmospheric conditions outside of the city. LCZ classification as described in Section 3.2 was used to obtain model input data on LU/LC, while initial meteorological data were taken from ALARO model and reference stations, described in Section 3.3. MUKLIMO_3 provides hourly micro-scale atmospheric information taking into account details of city structures with a horizontal resolution of $100 \mathrm{~m}$. Illustration of the model workflow is given in Fig. 1.

\subsection{Land use/land cover data}

The Local Climate Zone (LCZ) classification [58] has been used to define LU/LC distribution in the cities studied. The LCZ system was initially designed for the classification of urban measurement sites, but meanwhile several methods for LCZ mapping have been proposed [6,17,26,34]. For Kraków, Vienna, and Szeged, LCZs were delineated using the WUDAPT method (World Urban Database and Access Portal Tools; [5,6]). For the study areas 
22.00 CEST
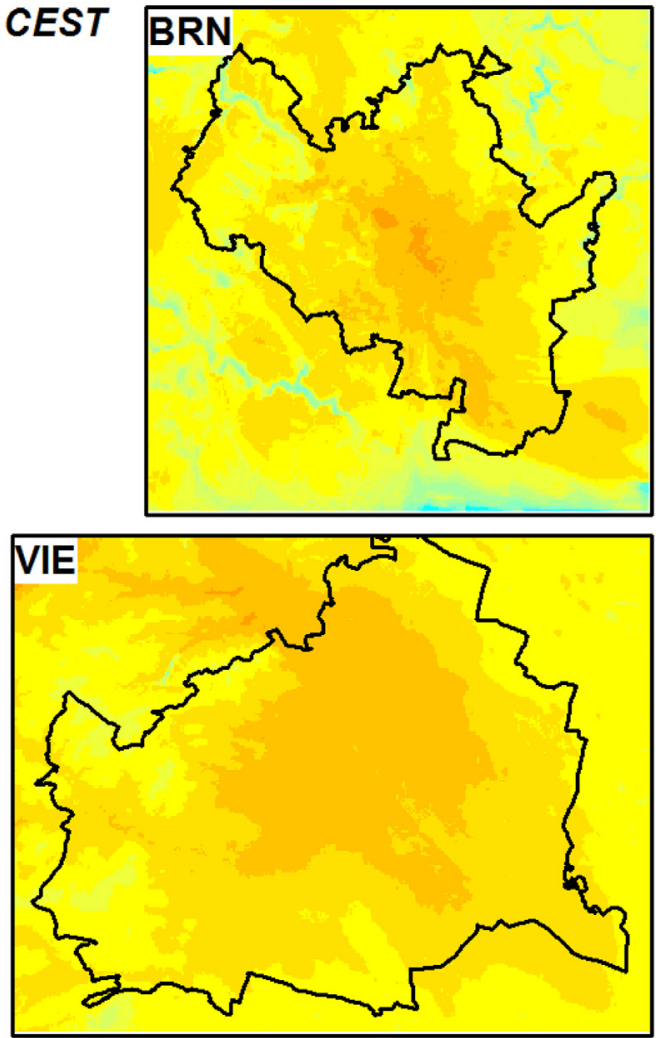

city administrative borders

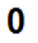

0 무

\section{KRW}

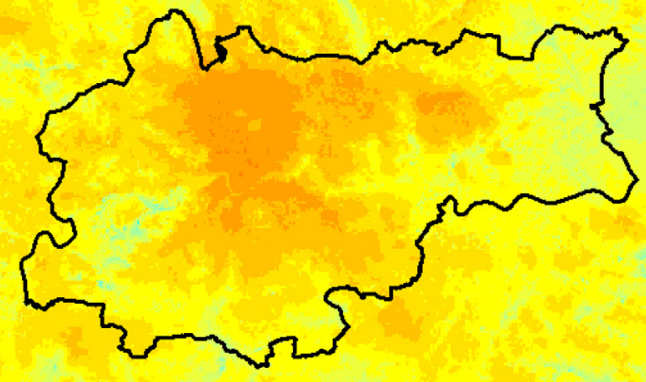

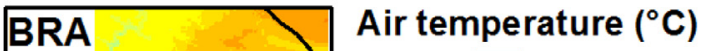

35

30

25
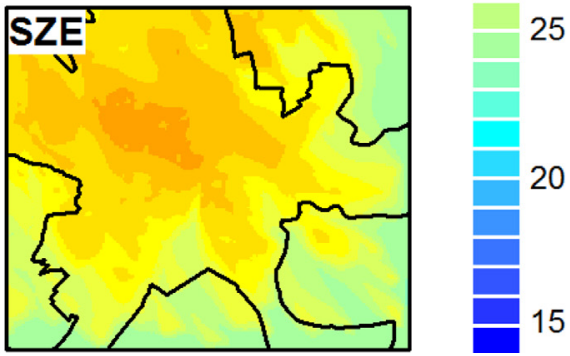

Fig. 6. Spatial distribution of modelled air temperature on 8th August at 22.00 in Bratislava (BRA), Brno (BRN), Kraków (KRW), Szeged (SZE) and Vienna (VIE).

Table 2

Reference stations for the cities studied.

\begin{tabular}{lllll}
\hline City & Station name & WMO ID & Altitude [m] & Coordinates \\
\hline Bratislava & Bratislava-Ivanka, airport & 11816 & 142 & $48.18^{\circ} \mathrm{N}, 17.20^{\circ} \mathrm{E}$ \\
Brno & Brno/Tuřany, airport & 11723 & 246 & $49.15^{\circ} \mathrm{N}, 16.68^{\circ} \mathrm{E}$ \\
Kraków & Kraków/Balice, airport & 12566 & 237 & $50.06^{\circ} \mathrm{N}, 19.78^{\circ} \mathrm{E}$ \\
Szeged & Szeged/HMS meteorological station & 12982 & 83 & $46.25^{\circ} \mathrm{N}, 20.08^{\circ} \mathrm{E}$ \\
Vienna & Groß-Enzersdorf & 11037 & 153 & $48.18^{\circ} \mathrm{N}, 16.55^{\circ} \mathrm{E}$ \\
\hline
\end{tabular}

included in the present paper we used multiple images from different seasons, as the classification gives better results with increased spectral information applied. Local environmental specifics in Brno and Bratislava did not allow the use of the WUDAPT method with sufficient accuracy, hence other LCZ classification methods were implemented $[17,26]$. LCZ maps of all the cities are presented in Fig. 2 and LCZs symbols are explained in Appendix B. LCZ composition in particular cities is an important factor affecting air temperature distribution which will be discussed further.

\subsection{Meteorological data}

Meteorological data for the MUKLIMO_3 model were obtained from the limited-area numerical weather prediction model ALARO (horizontal resolution of $4.8 \mathrm{~km}$ ) and from the measurements at reference stations located in rural areas close to the cities stud- ied. The ALARO model operated at the Zentralanstalt für Meteorologie und Geodynamik (ZAMG) uses the dynamical core that was previously developed for the ALADIN model [7,68], with a physics package specifically conceived to be run at convection-permitting scales [27]. The hydrostatic version of the model has been in deployment since 2011 performing integrations of up to 72-h lead time based on ECMWF IFS output. For the evaluation of the model performance during the summer heat wave period in 2015, information on the geopotential height, total cloud cover, and vertical profiles of temperature, humidity, and wind characteristics of the ALARO 00 UTC run with $+6 \mathrm{~h}$ forecast were extracted for a $4 \times 4$ grid domain close to the reference station of each city. In each city studied, a reference station was defined as a meteorological station with a standard range of measurements and located in a rural area close to the city, not directly affected by UHI (Table 2). 


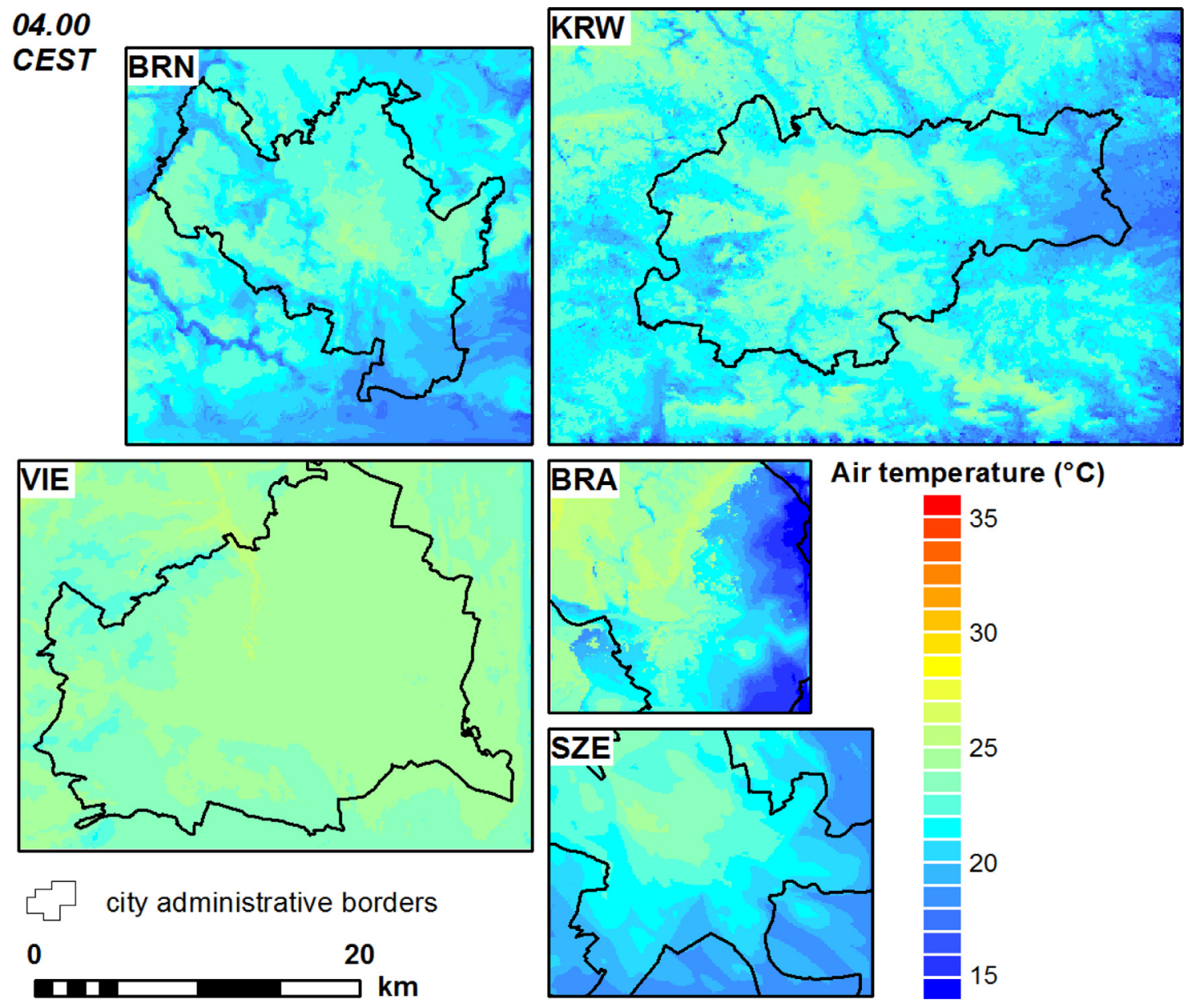

Fig. 7. Spatial distribution of air temperature on 9th August at 04.00 in Bratislava (BRA), Brno (BRN), Krakow (KRW), Szeged (SZE) and Vienna (VIE).

Table 3

Meteorological measurement networks operating in the cities studied.

\begin{tabular}{lll}
\hline City & No. of stations & $\begin{array}{l}\text { References with information } \\
\text { about networks }\end{array}$ \\
\hline Bratislava & 17 & {$[38]$} \\
Brno & 14 & {$[13,20]$} \\
Kraków & 22 & {$[10]$} \\
Szeged & 24 & {$[62]$} \\
Vienna & 9 & {$[21]$} \\
\hline
\end{tabular}

The data from measurement stations were first used to choose the study period. Apart from the criterion of maximum air temperature $\geq 30^{\circ} \mathrm{C}$, cloudiness and precipitation were considered. Only in Kraków were there two days with precipitation, i.e. 5th and 12th August, and those days were excluded from further analyzes owing to model limitations. Station data were used to provide some initial parameters for the model (Section 3.1). Additionally, in each city there exists a network of automatic measurement points used for model validation. Details about measurement networks are provided in Table 3.

\subsection{Statistical analyzes}

The first step of the model outputs analysis was the validation of model results with the measurement data from the period 4-14 August 2015. Two sample paired $t$-test and F-test were used for the air temperature measurement series for particular points from the automatic networks and the air temperature series for the same locations produced by the model. A Taylor diagram was used to present statistical parameters such as the Pearson correlation coefficient, the root-mean-square (RMS) error, and the standard deviation describing the correspondence between both types of data [59].

In the second step, the diurnal variability of spatial patterns of air temperature for particular cities, based on model outcomes, was analyzed. The heat wave was most intensive in the Central European region on 7th and 8th August 2015 [63]. 8th August was chosen for further analyzes instead of evaluating the entire heat wave. This approach was chosen with emphasis on the highest available accuracy of the simulation, owing to weather conditions dominated by processes driven by intensive solar radiation and lack of precipitation in all the cities studied. Based on the preliminary results, four terms were chosen for the analysis of the spatial pattern of air temperature (hours in CEST, i.e. UTC+2): 10.00 representing before-noon structure of UHI, 16.00 representing afternoon structure of UHI, 22.00 representing evening-time structure of UHI, and 04.00 of the subsequent day representing night-time structure of UHI. For each city and each of the hours mentioned, the model outputs in the form of a map of air temperature distribution were obtained, making it possible to analyze the influence of different landforms and LU/LC types (represented by LCZs). Heat load was defined with the following indices calculated for the hours chosen: 1. air temperature range in particular LCZs, compared in boxplots, 


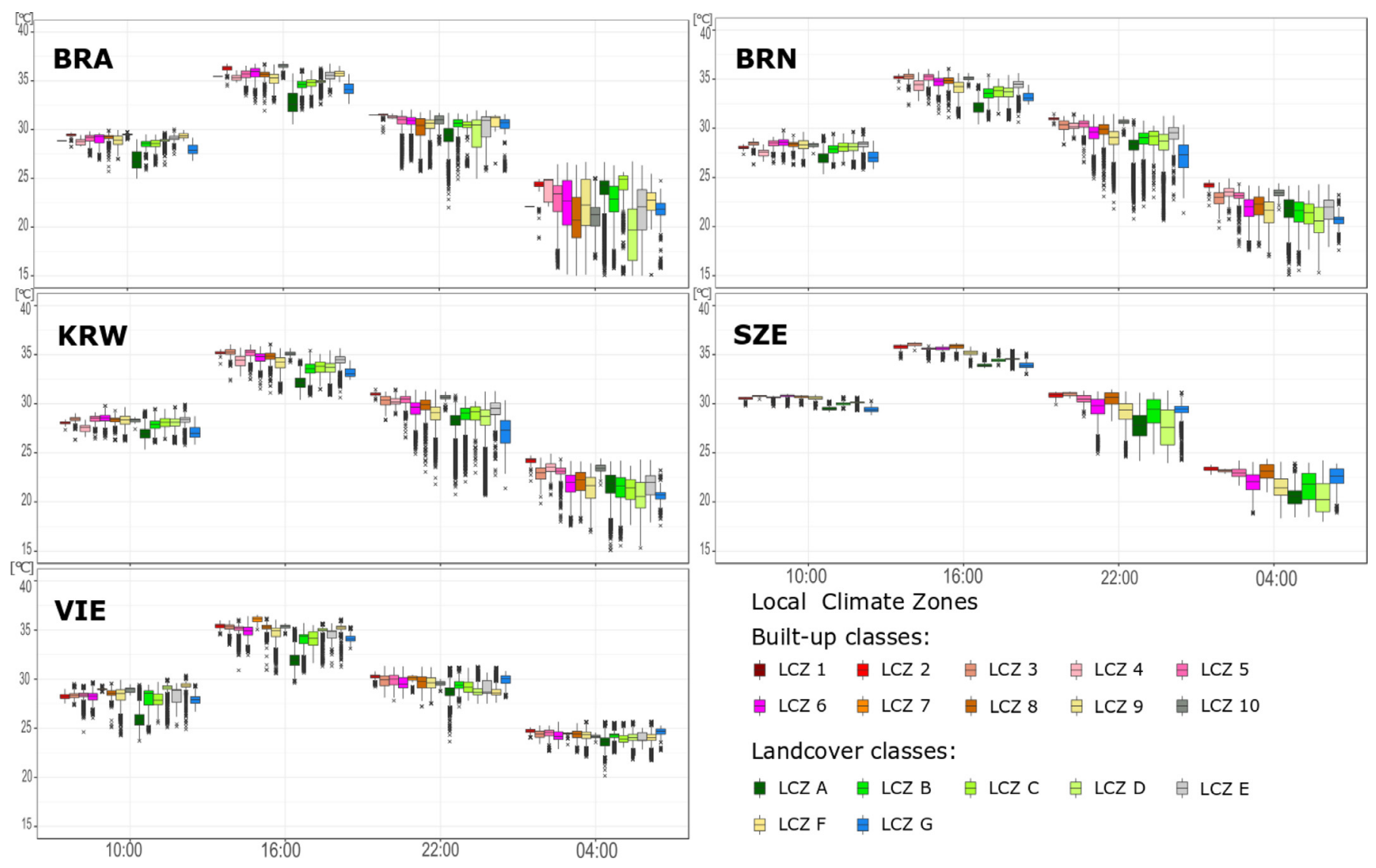

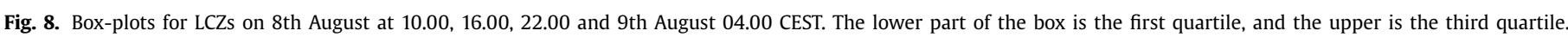
Whiskers indicate the lowest value still within $1.5 \mathrm{IQR}(\mathrm{IQR}=$ third quartile - first quartile) and the highest value still within $1.5 \mathrm{IQR}$. Black crosses indicate outliers.

2. air temperature diversity in urbanized (No. 1-10) and non-builtup (symbol A-G) LCZs defined with the median values range, i.e. the difference between the highest and the lowest median value in a particular LCZs group, 3 . the share of a city's area belonging to a particular $\mathrm{LCZ}$ with air temperature exceeding $25^{\circ} \mathrm{C}$ and $30^{\circ} \mathrm{C}$; for 04.00 the threshold $20^{\circ} \mathrm{C}$ was used additionally. Additionally, for each city except Szeged, the mean modeled air temperature was calculated for pixels belonging to LCZ 5 (i.e. open mid-rise) and located at different altitudes (Szeged is not included owing to low altitude variability) at $10.00,16.00,22.00$ and 4.00 CEST. LCZ 5 is the most common of the urban ones and therefore it can be used to see the impact of relief in urban areas.

\section{Results}

\subsection{Model validation}

In order to assess the model performance, the simulated hourly values of air temperature at $2 \mathrm{~m}$ above ground were compared with the hourly observational data from 86 measurement points (see table 3) during the heatwave period 4-14 August 2015. Statistical tests described in Section 3.4 were used (Appendix C) and the results, which were presented using a Taylor diagram (Fig. 3a), indicate that the model was able to describe the main features of the spatiotemporal variability of air temperature in all the analyzed cities. The simulated temperature values generally agree well with the observations. They have high correlation (between 0.80 and 0.95) and relatively low RMS errors (between $1{ }^{\circ} \mathrm{C}$ and $3^{\circ} \mathrm{C}$ ). The performance of the model varies primarily between different measurement points within the city, and secondarily between the cities, as is illustrated in Fig. 3a as well. The model results at most of the measurement points show a correlation higher than 0.90. Fig. 3b indicates the performance of the MUKLIMO_3 model and shows the mean hourly temperature bias averaged over all meteorological stations in each city during the heat wave event. The best model performance was achieved in Vienna (mean absolute error, MAE: $1.46^{\circ} \mathrm{C}$ ), followed by Szeged (MAE: $1.55^{\circ} \mathrm{C}$ ), Brno (MAE: $1.83^{\circ} \mathrm{C}$ ), Kraków (MAE: $2.12^{\circ} \mathrm{C}$ ) and Bratislava (MAE: $2.75^{\circ} \mathrm{C}$ ). The evaluation shows larger temperature biases in Kraków and Szeged during the evening time, whereas in Bratislava and Brno larger temperature biases occur in the morning hours.

\subsection{Spatiotemporal distribution of air temperature}

As mentioned in Section 3.4, 8th August was one of the hottest days in 2015 in all the cities (e.g. $[35,63]$ ) and therefore it was chosen for the study of spatiotemporal patterns of air temperature using the model outcomes. For the representativeness of the results, it is important to emphasize that the spatiotemporal pattern of air temperature on that day reflects well the general patterns for most of the other days of the heat wave. Based on the model simulations, the maximum daily temperatures were mostly between 32.0 and $37.0^{\circ} \mathrm{C}$ depending on the particular city and location. The day could be additionally considered as a hot day with a tropical night as during the following night the condition: $t_{\min } \geq 20.0^{\circ} \mathrm{C}$ was fulfilled in all cities analyzed. This section presents the spatial patterns of the elements of heat load (as defined in Section 3.4) for the four hours chosen, for all the cities studied. 
10.00 CEST
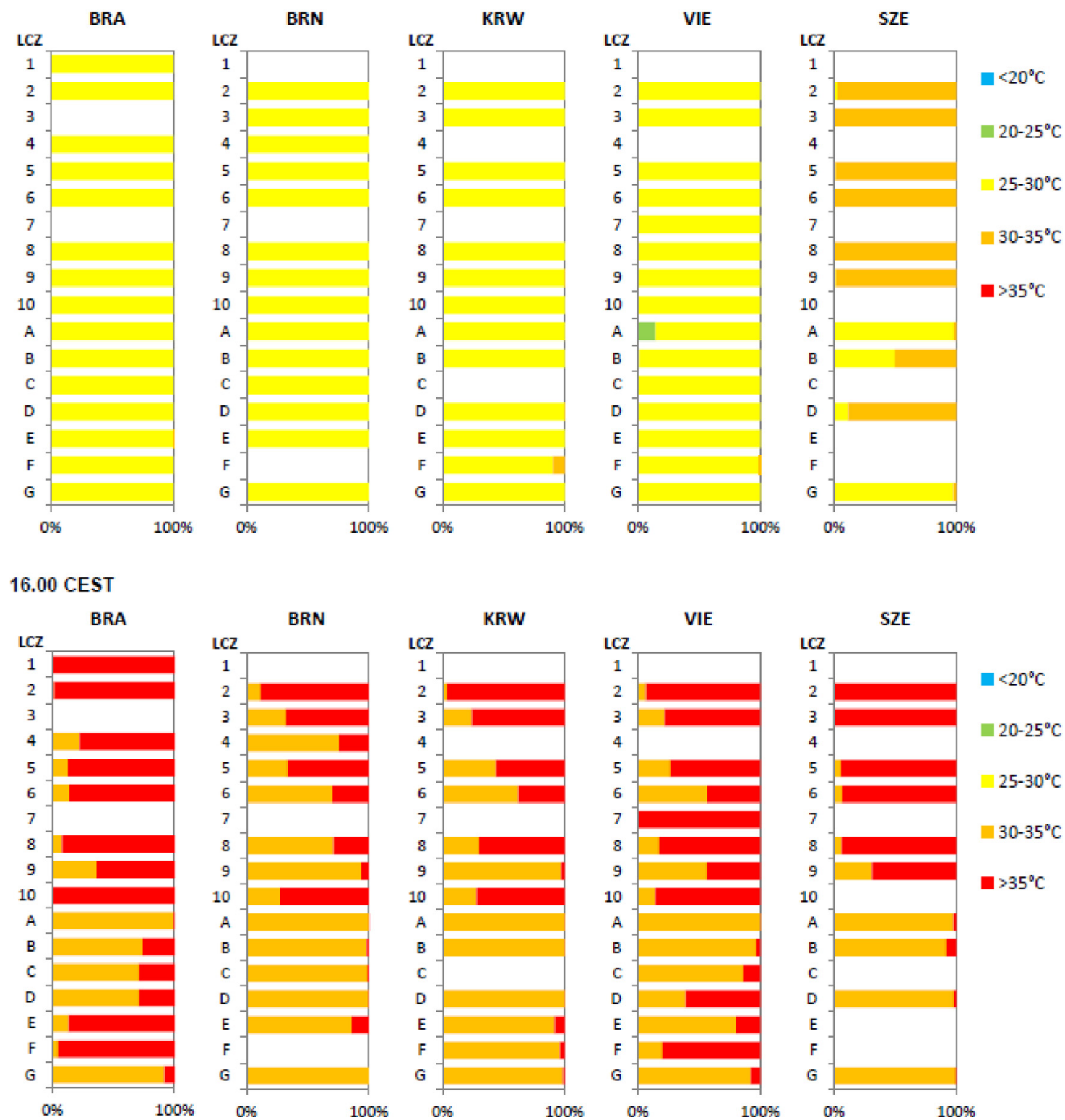

Fig. 9. Share (\%) of the LCZs area in particular cities with air temperature $<20^{\circ} \mathrm{C}, 20-25^{\circ} \mathrm{C}, 25-30^{\circ} \mathrm{C}, 30-35^{\circ} \mathrm{C}$ and $>35^{\circ} \mathrm{C}$ on 8 th August at $10.00,16.00,22.00$ and 9 th August 4.00 CEST. For explanations see App. B and Fig. 4.

Figs. 4-7 show the spatial distribution of modeled air temperature at the chosen moments of 8th August 2015. In the morning (10.00) the dominant influence of the relief on the formation of the air temperature pattern was observed; the modeled temperatures were predominantly higher in low locations than in areas located several tens of meters above the valley floors UHI was not distinctively formed in Bratislava, Brno, Kraków and Vienna but it had already begun to form in Szeged, where the relief variability is low (Fig. 4).

In the afternoon (16.00) air temperature reached the maximum daily values compared to other hours. In Brno, Bratislava, Kraków and Vienna, the model calculated that elevated locations (predominantly beyond the compact urban built-up area) remained relatively cooler. UHI was well developed in all cities studied and covered virtually all of the compact built-up areas (Fig. 5).
Spatial differentiation of temperature patterns increased at night, in a time of negative energetic balance, several hours after sunset (22.00). The influence of the relief was evident mainly in the narrow valleys near Bratislava, Brno and Kraków, where the model showed a rapid decrease of temperature while the air temperature in urbanized areas remained significantly higher (Fig. 6).

In the case of Szeged, the simulation showed most probably the effect of the advection of warmer air from the city to the surrounding countryside. In Bratislava, Brno, Kraków, and Vienna, in rural areas, air temperature inversion can be observed, i.e. air temperature in the valley floors is the lowest compared to the surrounding slopes and hilltops.

Late at night (04.00) UHI was well-developed and maximum UHI magnitude values (which occurred at different hours in particular cities, according to the measurement data) reached $6.4 \mathrm{~K}$ in Bratislava, $5.7 \mathrm{~K}$ in Brno and in Kraków, $5.4 \mathrm{~K}$ in Szeged, and 5.0 in 


\subsection{CEST}
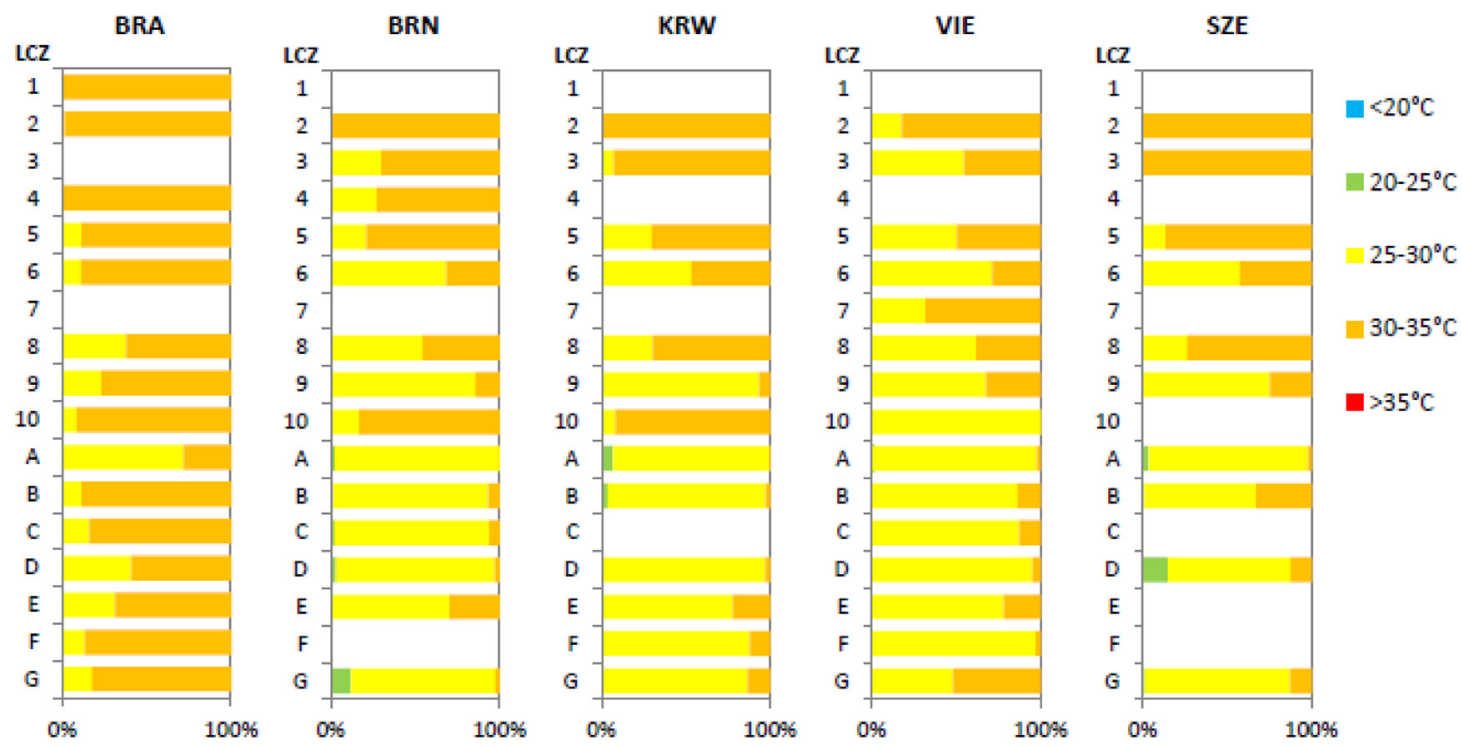

\subsection{CEST}
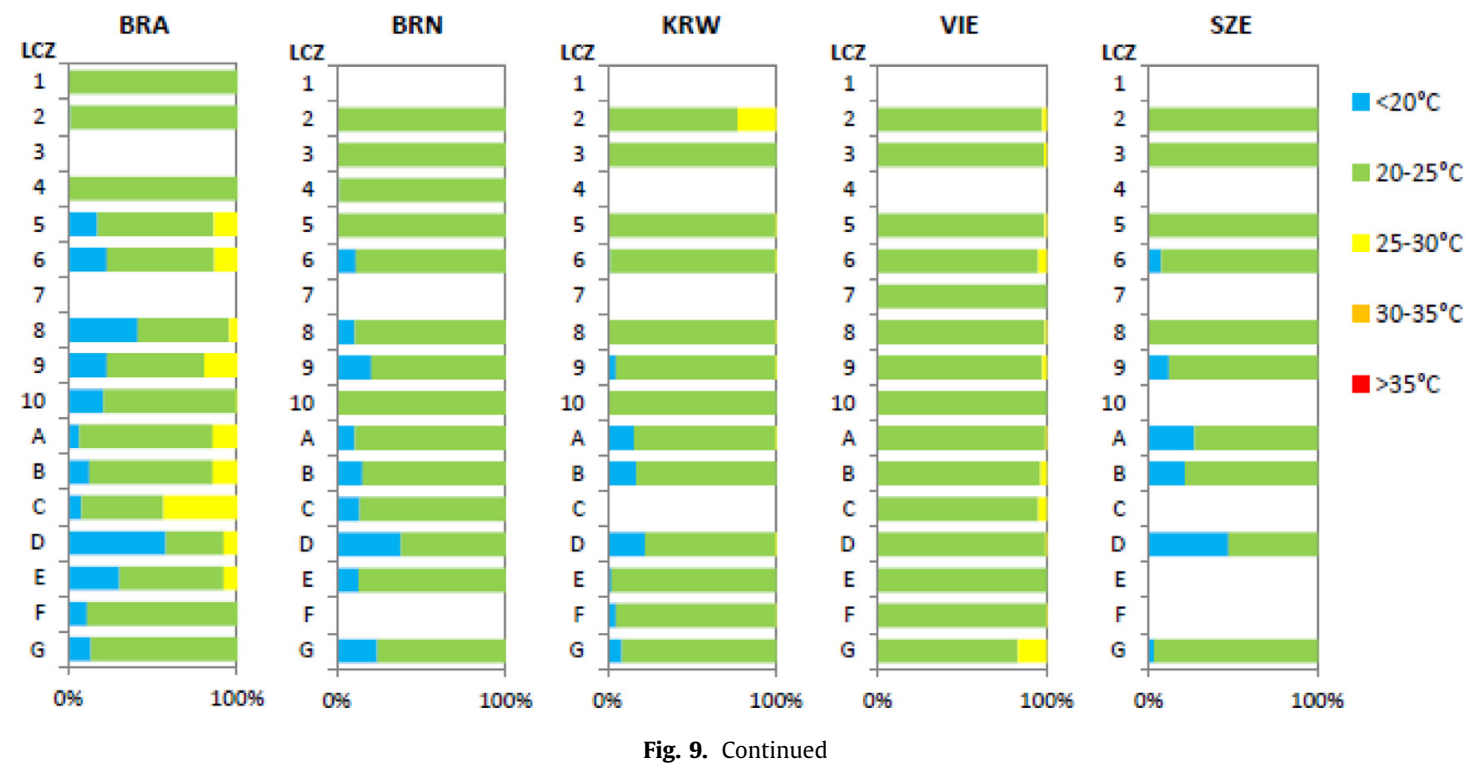

Vienna. The model simulations showed air temperature inversions, with higher temperatures to be found in elevated locations than in the valleys (Fig. 7).

Fig. 8 provides data to study air temperature range in particular LCZs air temperature diversity in urbanized (No. 1-10) and non-built-up (symbol A-G) LCZs defined with the median values range, i.e. the difference between the highest and the lowest median value in a particular LCZs group. At 10:00, the air temperature range observed in particular LCZs is much smaller in Szeged than in other cities which is linked to its southernmost location and the earliest sunrise hour. At 10:00, 16:00 and 22:00, thermal conditions were more diversified in non-built-up areas (LCZs A-G) than in urbanized ones (LCZs 1-10), except Kraków at 22:00. Median range for LCZs A-G reached: from $0.7 \mathrm{~K}$ in Szeged to 3.5 in Vienna, from $0.7 \mathrm{~K}$ in Szeged to $3.3 \mathrm{~K}$ in Vienna, and from $1.4 \mathrm{~K}$ in Vienna to $2.3 \mathrm{~K}$ in Brno, respectively. For LCZs $1-10$ the values were from $0.2 \mathrm{~K}$ in Szeged to $1.0 \mathrm{~K}$ in Vienna, from $0.9 \mathrm{~K}$ in Szeged to $1.4 \mathrm{~K}$ in Kraków, and from $0.8 \mathrm{~K}$ in Vienna to $1.9 \mathrm{~K}$ in Brno (while in Kraków: $1.5 \mathrm{~K}$ and $2.7 \mathrm{~K}$ ), respectively. In the case of the cities studied, land use/land cover of rural areas is much less diversified than that of urban ones but it is the opposite with the relief (Fig. 2), and that is the reason for the difference in median values mentioned above.

At 4:00, in the case of urbanized areas (LCZ 1-10), the median range was much larger in Bratislava $(4.1 \mathrm{~K})$, Brno $(2.6 \mathrm{~K})$, and Kraków $(2.9 \mathrm{~K})$ than in Vienna $(0.6 \mathrm{~K})$ and Szeged $(2.0 \mathrm{~K})$. In the rural areas (LCZ A-G), the median range in Bratislava $(5.2 \mathrm{~K}$ ) was much larger than in the remaining cities (from $1.4 \mathrm{~K}$ in Brno to $2.4 \mathrm{~K}$ in Vienna and Szeged). In Kraków, similarly to the situation at 22.00 , the thermal conditions were still more diversified in urbanized areas than in non-urbanized ones and the same pattern occurred in Brno, while in other cities it was the opposite. At 04.00, the intra-class variability of air temperature, i.e. large temperature differences within particular LCZs, reached maximum values of about $5 \mathrm{~K}$ in Bratislava, and those were the highest values from all hours in all cities compared.

Figs. 9 and 10 show the share of a city's area belonging to a particular $\mathrm{LCZ}$ with air temperature exceeding $25^{\circ} \mathrm{C}$ and $30^{\circ} \mathrm{C}$; 


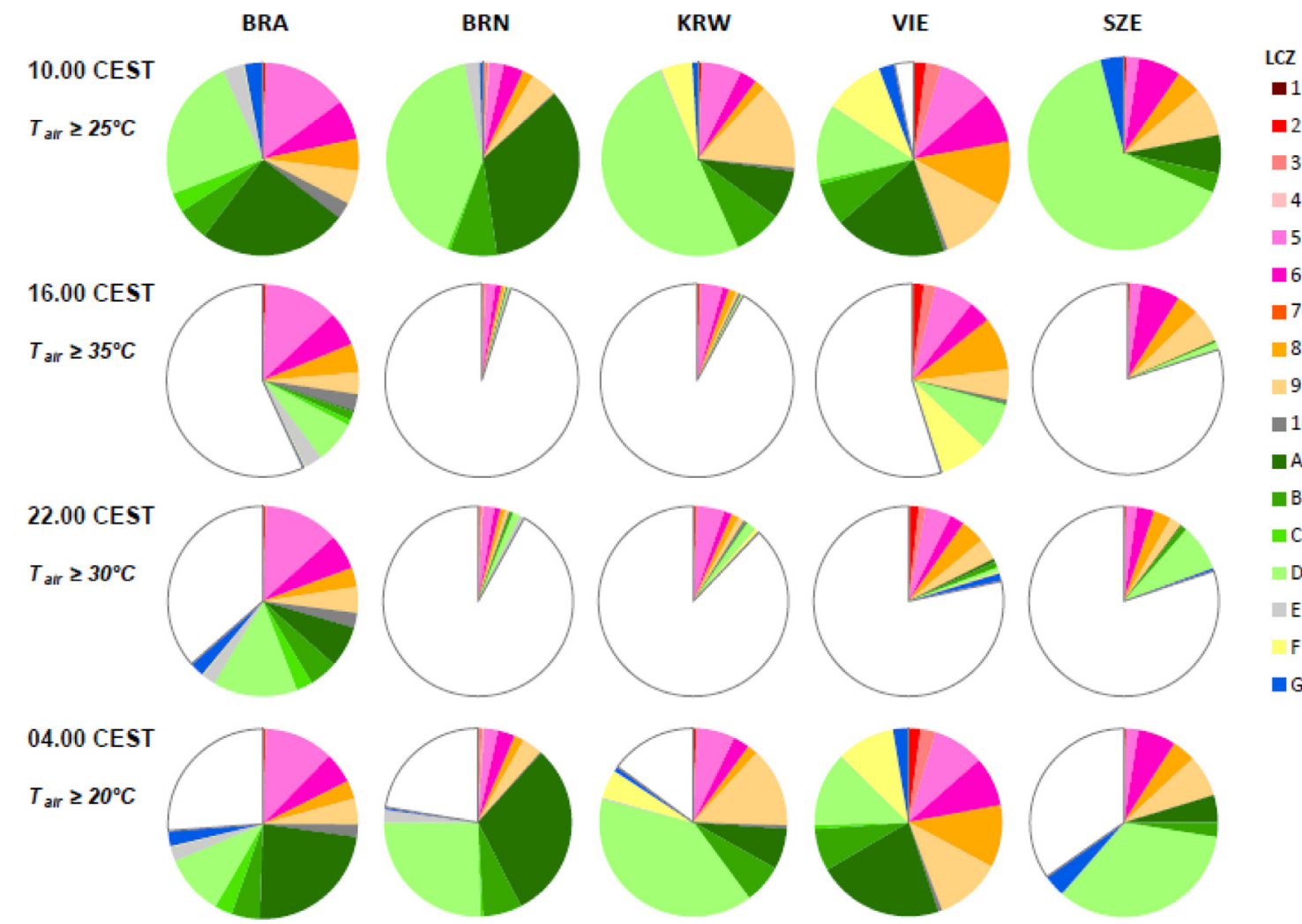

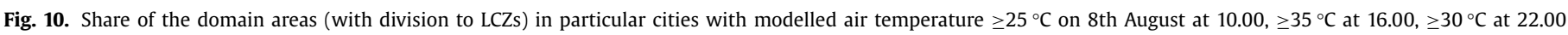
and $\geq 20^{\circ} \mathrm{C}$ on 9 th August at 4.00 . For explanations see App. B and Fig. 4.

for 04.00 the threshold $20^{\circ} \mathrm{C}$ was used additionally. At 22:00, in all cities and in all LCZs that threshold of $25^{\circ} \mathrm{C}$ had already been reached all over their area, with the exception of LCZ A in Vienna where $13.8 \%$ of the area had a lower air temperature. The threshold of $30{ }^{\circ} \mathrm{C}$ was exceeded in Szeged in $97-100 \%$ of the areas belonging to LCZs 1-10 while in rural areas the share increased from about $2.1 \%$ in LCZ A to about $90.3 \%$ in LCZ D. In other cities, the air temperature exceeded $30{ }^{\circ} \mathrm{C}$ only in the case of LCZ F in Kraków (10.1\% of the zone area) and Vienna (1.2\%). At 16:00, in all the cities, the threshold of $30^{\circ} \mathrm{C}$ was exceeded all over their areas and a temperature above $35{ }^{\circ} \mathrm{C}$ occurred in $43.1 \%$ of the area in Bratislava, $4.9 \%$ in Brno, 8.0\% in Kraków, 45.2\% in Vienna, and 20\% in Szeged. In Brno, Kraków, and Szeged, such a high air temperature occurred almost exclusively in urbanized areas, but in Bratislava and Vienna quite a large share belonged to non-urbanized areas. At 22:00, the threshold of $25^{\circ} \mathrm{C}$ was exceeded in all the cities all over their areas, but there were three exceptions, i.e. LCZs areas where the share was below 90\%: LCZ D in Vienna (89.1\%) and Szeged (84.6\%) and LCZ G in Brno (87.8\%). However, a more important issue is the occurrence of air temperatures above $30^{\circ} \mathrm{C}$, in spite of such a late hour, as was noted in $63.5 \%$ of the area in Bratislava, $8.1 \%$ in Brno, $12.1 \%$ in Kraków, $21.6 \%$ in Vienna and $19.8 \%$ in Szeged. So high air temperature was predicted by the model mainly for urbanized areas. There are no regularities common for all cities. In the case

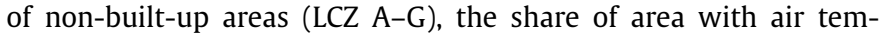
perature exceeding $30^{\circ} \mathrm{C}$ is much larger in Bratislava (28.4-88.6\%) than in other cities $(0.1-52.4 \%)$. There are two major factors which are responsible for the higher values: 1) the elevated and densely forested mountain area in the northern part of the Bratislava domain is generally oriented to the south. Other cities are located either in flatter areas (like Szeged) or their area is much more complex (in the case of Brno); 2) land cover classes in Bratislava are quite specific (see Fig. 2a). LCZ A is often oriented to the south (as mentioned above), and parallel, large areas of LCZ E can be found mainly in the southern part. The ratio of these classes is, in comparison with other cities, significantly higher. Additionally, LCZ A-G are relatively close to built-up areas and may be more influenced by UHI than are remote non-urbanized areas of other cities. The presence of heavy industry mainly in the SE part of the city may influence the temperature in surrounding rural areas as well. At 4:00, air temperature did not exceed the threshold of $30^{\circ} \mathrm{C}$ in any city, but the threshold of $25^{\circ} \mathrm{C}$ was exceeded in Bratislava, Kraków, and Vienna. In Kraków it was mainly in LCZ 2 (26.5\% of the area with that LCZ type). In Vienna, air temperature was above $25^{\circ} \mathrm{C}$ mainly in LCZ E (7.3\% of the area) and in 6 (5.2\%). In comparison to those two cities, Bratislava is a city with a much larger heat load. In urbanized areas, the threshold of $25^{\circ} \mathrm{C}$ was exceeded in LCZ 5 , $6,8$, and 9 (4.8\% to $21.2 \%)$ and in rural areas in all LCZs except G ( $2.2 \%$ to $46.3 \%)$. The threshold was not exceeded in any city in LCZs $1,4,7$, and G. As already mentioned, it was a so-called tropical night and air temperature was above $20^{\circ} \mathrm{C}$ in each city and each LCZ. The share of area of the domain with that threshold exceeded was $73.9 \%$ in Bratislava, $77.6 \%$ in Brno, $85.1 \%$ in Kraków, $65.3 \%$ in Szeged, and $100 \%$ in Vienna.

Fig. 11 shows mean modeled air temperature for pixels belonging to LCZ 5 (i.e. open mid-rise) and located at different altitudes. At 10:00, the differences were from 0.7 in Kraków to 2.2 in Vienna. At 16:00, they reached about $2 \mathrm{~K}$ in all cities, which shows the contribution of concave landforms to higher heat load compared with the convex landforms. At 22:00, temperature inversion can be observed in the air stratum from the valley floor up to $50 \mathrm{~m}$ above it in Bratislava, Brno, and Kraków, while higher up temperature decreases with higher altitude. At 4:00, in Bratislava, Brno, and Kraków, in LCZ 5 the inversion in the stratum of $50 \mathrm{~m}$ above the valley floor intensified comparing to 22.00, while in Vienna a slight air temperature decrease in the whole profile was observed. 

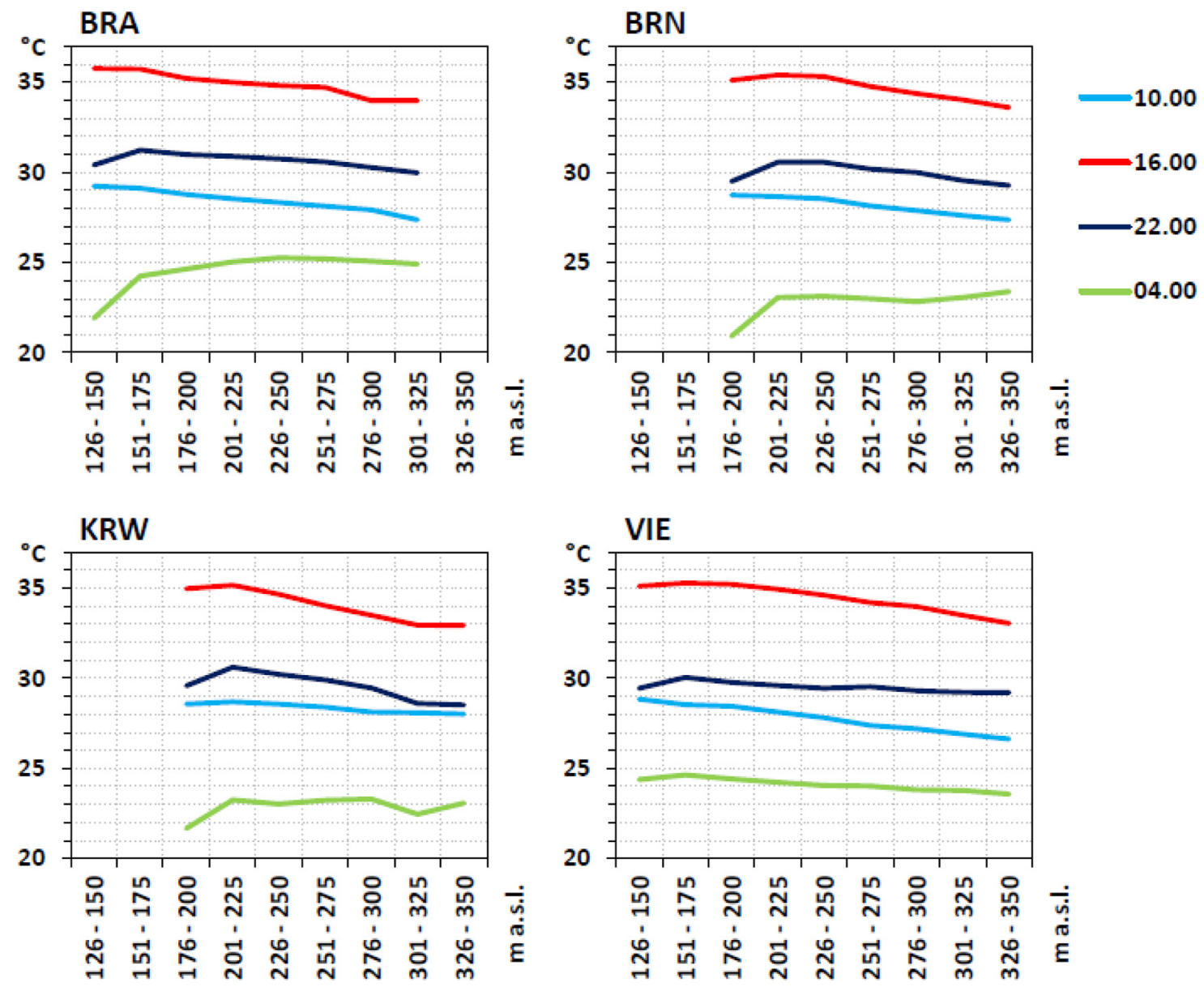

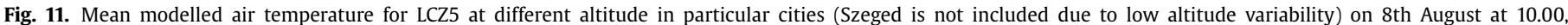
16.00, 22.00 and 9th August 4.00 CEST. For explanations see App. B and Fig. 4.

\section{Discussion and conclusion}

The analyzes presented above show that the heat load pattern (as defined in Section 3.4) varied among the cities studied. The median range is an index that indicates the degree of air temperature spatial variability and in the present study it showed significant differences among the five cities. In Bratislava median ranges for particular hours differ a lot, both in urban (from $0.7 \mathrm{~K}$ at 10.00 to $4.1 \mathrm{~K}$ at 04.00 ) and rural LCZs (from $1.8 \mathrm{~K}$ at 22.00 to $5.2 \mathrm{~K}$ at 04.00). This is a united effect of both the model performance (i.e. underestimation of the temperature in the easternmost part of the city) and the impact of the relief; according to the measurement data used to validate the model, there can be a difference of about $3{ }^{\circ} \mathrm{C}$ in air temperature between two stations in the same LCZ type, but with different relative altitudes. There is a possibility that it is a result of the influence of the neighboring LCZs. Some of the meteorological stations used for validation are placed along the motorway network and usually belong to LCZ class E (bare rock or paved). However this class is usually represented by narrow and long areas and therefore the influence of the neighborhood should not be omitted. The least differentiated median ranges are those for Vienna in the case of urban ones (from $0.6 \mathrm{~K}$ at 04.00 to $1.2 \mathrm{~K}$ at 16.00 ) and those for Kraków for rural ones (from $1.6 \mathrm{~K}$ at 04.00 to $1.9 \mathrm{~K}$ at 16.00). Except in Vienna, the air temperature ranges in particular LCZs have a tendency to increase from morning till nighttime. At 22.00 and 4.00, in Bratislava, Brno, and Kraków, there are a large number of outlier air temperature values for most LCZ types (Fig. 8) which can be linked to the air temperature inver- sions; in such situations areas belonging to the same LCZ can be located e.g. under or above the inversion layer, and the relief impact will be decisive in the formation of an air temperature pattern. At 10.00 , the threshold of $30^{\circ} \mathrm{C}$ was exceeded practically only in Szeged and for that hour Szeged can be considered the city with the largest heat load, as in many urban LCZs (1-10) the median values were the largest compared with other cities. The main reason may be the southernmost location of Szeged in comparison to other cities studied. Following the criterion of the largest number of urban LCZ types with the highest median values, at 16.00 , both Szeged and Bratislava seem to have experienced comparable levels of heat load, larger than the other cities; at 22.00 those are Bratislava and Kraków, while at 4.00 it is Vienna. Regarding urban LCZs with the highest heat load, LCZ 2 and 3 have the highest median values in most cities from 16.00 to 4.00 , while at 10.00 there is no such clear pattern and in each city a different LCZ can be considered as the one which experiences the highest air temperature. Also taking into consideration the percentage of LCZ areas with an air temperature above $30^{\circ} \mathrm{C}$ at 22.00 (as at other hours that criterion does not show differences among the cities), LCZ 2 is the one with the highest heat load. LCZ 9, on the contrary, can be considered the one with the lowest heat load as regards the median values.

The results indicate that in the case of the cities studied, UHI needs to be considered as an element of a complicated spatial pattern of air temperature which seems to be substantially influenced by processes generated by the surrounding landforms, as suggested in earlier empirical studies (e.g. [10]). The intra-zonal 
and inter-zonal variability of air temperatures, and in particular LCZs, is largely the same in cities with a similar type of relief, i.e. in Brno and Kraków, which are surrounded by hills and in Bratislava and Vienna which have some hills on one side but an open wide valley on the other one. Szeged, on the contrary, is located in an area with little diversified relief, so there are no katabatic flows or cold air reservoirs being formed during the night. On the basis of the model simulation results, it can be summarized that in the morning (forenoon) hours of a hot day during a heat wave, unshaded open localities (particularly LCZ D or LCZ F) are relatively warmer than other LCZs as well as localities with open low or mid-rise development with a high percentage of impervious surface fraction (particularly LCZ 10). This pattern of air temperature in the forenoon agreed well with a land surface temperature differentiation of LCZs [18]. In the afternoon, the air temperature pattern with the highest values in densely built-up areas (esp. LCZ 2, LCZ 3, LCZ 8 and LCZ 10) was formed. Particularly in Brno, Kraków, and Szeged this pattern generally lasted until 04.00. Simulated nocturnal air temperature differences among LCZs particularly in Brno, Kraków, and Szeged correspond generally well with those empirically measured in those [33,34] and other cities (e.g. [1,32]). In Vienna and Bratislava, most probably the local circulation patterns substantially influenced results. Consequently, nocturnal air temperature differences among LCZs were lower than in the afternoon regardless of the fact that afternoon temperature differences between particular types of LU/LC (LCZs) are usually less pronounced as air is mixed owing to the well-developed turbulence $[40,41,56]$. It should be noted, however, that during the nocturnal cooling, simulations of the MUKLIMO_3 are generally less accurate $[19,20]$. Additionally, some microclimatic effects (e.g. connected with the pre-heating of the buildings on preceding days) cannot be included in the analyzes, owing to the model limitations.

The modeling of spatial patterns of urban climate and validation of model results is one of the main challenges in contemporary urban climate research. Our attempt to model spatiotemporal patterns of air temperature during the 2015 heat wave event in five Central European cities showed that MUKLIMO_3 is able to properly simulate the main features of the temperature pattern in urban areas. The accuracy of models based on RANS, where the entire turbulence spectrum is parameterized, is limited, but the model was able to provide accurate and valuable information for many purposes. Nevertheless, any further application of the model to cities worldwide is limited by input data and their validation availability [20], and insufficient validation of model results is one of the major problems of urban climate modeling [43]. For instance, in the case of LU/LC data we uniformly used the LCZ concept, however the non-uniform quality of data entering the LCZ classification, the chosen classification algorithm itself, or the selection of training areas could affected the results [17,66]. Therefore in agreement with Hammerberg et al. [25] we encourage the scientific community to work on the unification of geodatabases for urban areas for RANS-based modeling, with a preference for higher accuracy.

The results of the analyzes presented showed the occurrence of very high temperatures particularly in densely urbanized areas, and they should be included in urban spatial planning procedures. The spatial variability of air temperature in particular LCZs shows that there is no simple connection between LU/LC and air temperature, and the local impact of relief has to be taken into consideration; e.g. the highest day time air temperatures occur in valley floors. The role of green areas in the modification of air temperature in urban areas is complex, too; open green areas with little shade can contribute to the generation of relatively high air temperature while forested areas experience relatively lower temperatures. To get a deeper understanding of the influence of those factors, further work on the refinement of model outputs and their validation is necessary. Only accurate information on the factors affecting the urban climate will lead to well-tailored measures to mitigate thermal stress and reduce its health impact in urban areas.

\section{Conflict of interest}

None

\section{Acknowledgements}

The results presented in the paper were partially obtained within the project "Urban climate in Central European cities and global climate change" which has been realized within the framework of the International Visegrad Fund Standard Grant no. 21410222 in the years 2014-2015. J. Holec, P. Št’astný and M. Garaj want to acknowledge the project "Effect of impermeable soil cover on urban climate in the context of climate change" supported by Slovak Research and Development Agency under contract no. APVV-15-0136. This study was supported by the Ministry of Human Capacities, Hungary grant 20391-3/2018/FEKUSTRAT. N. Skarbit and T. Gál were supported by NKFI 120346. M. Žuvela-Aloise and B. Hollósi want to acknowledge Austrian Federal Ministry of Education, Science and Research.

\section{Appendix A}

Mean annual air temperature $(\mathrm{T})$ and precipitation $(\mathrm{P})$ in the cities studied in the period 1971-2000

\begin{tabular}{|c|c|c|c|c|c|c|}
\hline City & $\begin{array}{l}\text { Station } \\
\text { name }\end{array}$ & WMO ID & $\begin{array}{l}\text { Altitude } \\
\text { [m a.s.l.] }\end{array}$ & Coordinates & $\mathrm{T}\left({ }^{\circ} \mathrm{C}\right)$ & $\mathrm{P}(\mathrm{mm})$ \\
\hline Bratislava & $\begin{array}{l}\text { Bratislava- } \\
\text { Ivanka }\end{array}$ & 11816 & 142 & $\begin{array}{l}48.18^{\circ} \mathrm{N} \\
17.20^{\circ} \mathrm{E}\end{array}$ & 10.1 & 557 \\
\hline Brno & $\begin{array}{l}\text { Brno/ } \\
\text { Tuřany }\end{array}$ & 11723 & 246 & $\begin{array}{l}49.15^{\circ} \mathrm{N} \\
16.68^{\circ} \mathrm{E}\end{array}$ & 9.0 & 479 \\
\hline Kraków & Kraków & 12566 & 237 & $\begin{array}{l}50.06^{\circ} \mathrm{N} \\
19.78^{\circ} \mathrm{E}\end{array}$ & 8.1 & 667 \\
\hline Szeged & Szeged & 12982 & 83 & $\begin{array}{l}46.25^{\circ} \mathrm{N} \\
20.08^{\circ} \mathrm{E}\end{array}$ & 10.6 & 499 \\
\hline Vienna & $\begin{array}{l}\text { Wien/Hohe- } \\
\text { Warte }\end{array}$ & 11035 & 209 & $\begin{array}{l}48.25^{\circ} \mathrm{N} \\
16.37^{\circ} \mathrm{E}\end{array}$ & 10.2 & 615 \\
\hline
\end{tabular}

Source of data: NOAA/NCEI GHCN data base.

\section{Appendix B}

Parameters for land cover properties in MUKLIMO_3 model: fraction of built area $\left(\gamma_{b}\right)$, mean building height $\left(h_{b}\right)$, wall area in$\operatorname{dex}\left(w_{b}\right)$, fraction of pavement of the non-built area $(v)$, fraction of tree cover $\left(\sigma_{t}\right)$ and fraction of low vegetation of the remaining surface $\left(\sigma_{\mathrm{c}}\right)$, tree height $\left(\mathrm{h}_{\mathrm{t}}\right)$ and height of the low vegetation $\left(\mathrm{h}_{\mathrm{c}}\right)$. Fractions $\gamma_{\mathrm{b}}$ and $\sigma_{\mathrm{t}}$ are relative to the total grid cell area. Fraction $\mathrm{v}$ is relative to the area without buildings and trees and $\sigma_{\mathrm{c}}$ is relative to the remaining surface.

\begin{tabular}{|c|c|c|c|c|c|c|c|c|}
\hline $\begin{array}{l}\text { Local Climate } \\
\text { Zones }\end{array}$ & $\begin{array}{l}\gamma_{\mathrm{b}} \\
(\%)\end{array}$ & $\mathrm{h}_{\mathrm{b}}(\mathrm{m})$ & $\mathrm{w}_{\mathrm{b}}$ & $\mathrm{V}(\%)$ & $\begin{array}{l}\sigma_{\mathrm{t}} \\
(\%)\end{array}$ & $\begin{array}{l}\sigma_{\mathrm{c}} \\
(\%)\end{array}$ & $\begin{array}{l}\mathrm{h}_{\mathrm{t}} \\
(\mathrm{m})\end{array}$ & $\begin{array}{l}\mathrm{h}_{\mathrm{c}} \\
(\mathrm{m})\end{array}$ \\
\hline $\begin{array}{l}1 \text { Compact } \\
\text { high-rise }\end{array}$ & 0.60 & 25.00 & 6.67 & 1.00 & 0.00 & 0.90 & 0.0 & 0.10 \\
\hline $\begin{array}{l}2 \text { Compact } \\
\text { midrise }\end{array}$ & 0.45 & 16.50 & 3.42 & 0.70 & 0.00 & 0.90 & 0.0 & 0.10 \\
\hline $\begin{array}{l}3 \text { Compact } \\
\text { low-rise }\end{array}$ & 0.45 & 9.20 & 2.40 & 0.40 & 0.00 & 0.80 & 0.0 & 0.10 \\
\hline 4 Open high-rise & 0.30 & 25.00 & 7.00 & 0.20 & 0.00 & 0.60 & 0.0 & 0.10 \\
\hline 5 Open midrise & 0.30 & 18.60 & 4.40 & 0.45 & 0.00 & 0.80 & 0.0 & 0.10 \\
\hline 6 Open low-rise & 0.30 & 6.50 & 2.10 & 0.40 & 0.00 & 0.70 & 0.0 & 0.10 \\
\hline
\end{tabular}




\begin{tabular}{|c|c|c|c|c|c|c|c|c|c|}
\hline \multicolumn{2}{|r|}{$\begin{array}{l}\text { Local Climate } \\
\text { Zones }\end{array}$} & \multirow{2}{*}{$\begin{array}{l}\gamma_{\mathrm{b}} \\
(\%)\end{array}$} & \multirow{2}{*}{$\begin{array}{l}\mathrm{h}_{\mathrm{b}}(\mathrm{m}) \\
3.00\end{array}$} & \multirow{2}{*}{$\begin{array}{l}\mathrm{w}_{\mathrm{b}} \\
1.80\end{array}$} & \multirow{2}{*}{$\begin{array}{l}\mathrm{V}(\%) \\
0.20\end{array}$} & \multirow{2}{*}{$\begin{array}{l}\begin{array}{l}\sigma_{\mathrm{t}} \\
(\%)\end{array} \\
0.00\end{array}$} & \multirow{2}{*}{$\begin{array}{l}\begin{array}{l}\sigma_{\mathrm{c}} \\
(\%)\end{array} \\
0.30\end{array}$} & \multirow{2}{*}{$\left.\begin{array}{l}\mathrm{h}_{\mathrm{t}} \\
(\mathrm{m})\end{array}\right)$} & \multirow{2}{*}{$\begin{array}{c}\begin{array}{l}\mathrm{h}_{\mathrm{c}} \\
(\mathrm{m})\end{array} \\
0.10\end{array}$} \\
\hline 7 & $\begin{array}{l}\text { Lightweight } \\
\text { low-rise }\end{array}$ & & & & & & & & \\
\hline 8 & Large low-rise & 0.40 & 6.80 & 2.00 & 0.80 & 0.00 & 80 & 1.0 & 0.10 \\
\hline 9 & Sparsely built & 0.15 & 8.50 & 2.10 & 0.45 & 0.00 & 0.80 & 0.0 & 0.10 \\
\hline 10 & Heavy industry & 0.50 & 18.00 & 2.00 & 0.80 & 0.00 & 0.80 & 0.0 & 0.10 \\
\hline A & Dense trees & 0.00 & 0.00 & 0.00 & 0.00 & 0.80 & 0.90 & 21.0 & 0.50 \\
\hline B & Scattered trees & 0.00 & 0.00 & 0.00 & 0.00 & 0.40 & 0.90 & 14.0 & 0.50 \\
\hline c & Bush. scrub & 0.00 & 0.00 & 0.00 & 0.00 & 0.40 & 0.90 & 2.0 & 0.50 \\
\hline D & Low plants & 0.00 & 0.00 & 0.00 & 0.00 & 0.00 & 1.00 & 0.2 & 0.50 \\
\hline E & $\begin{array}{l}\text { Bare rock or } \\
\text { paved }\end{array}$ & 0.00 & 0.00 & 0.00 & 0.95 & 0.00 & 0.01 & 0.0 & 0.30 \\
\hline $\mathrm{F}$ & $\begin{array}{l}\text { Bare soil or } \\
\text { sand }\end{array}$ & 0.00 & 0.00 & 0.00 & 0.00 & 0.00 & 0.01 & 0.0 & 0.30 \\
\hline G & Water & 0.00 & 0.00 & 0.00 & -1.00 & 0.00 & 0.01 & 0.0 & 0.30 \\
\hline
\end{tabular}

\section{Appendix C}

Results of two sample $t$-test and two sample f-test for measured and modelled data from measurement points (m.p.) in particular cities on 8th and 9th August 2015.

\begin{tabular}{|c|c|c|c|c|c|}
\hline \multirow[t]{2}{*}{ City } & \multirow[t]{2}{*}{ m.p. } & \multicolumn{2}{|c|}{ two sample $t$-test } & \multicolumn{2}{|c|}{ two sample f-test } \\
\hline & & 2015-08-08 & 2015-08-09 & 2015-08-08 & 2015-08-09 \\
\hline \multirow[t]{17}{*}{ BRA } & 11,810 & 0.722 & 0.639 & 0.587 & 0.360 \\
\hline & 11,813 & 0.917 & 0.660 & 0.851 & 0.243 \\
\hline & 11,816 & 0.366 & 0.820 & 0.146 & 0.572 \\
\hline & 40,001 & & & & \\
\hline & 40,002 & & & & \\
\hline & 40,003 & 0.110 & $0.028^{*}$ & 0.417 & 0.709 \\
\hline & 37,379 & 0.358 & $0.020^{*}$ & 0.164 & 0.853 \\
\hline & 37,380 & 0.632 & 0.209 & 0.165 & 0.770 \\
\hline & 37,381 & 0.094 & 0.080 & 0.555 & 0.985 \\
\hline & 37,382 & 0.088 & 0.147 & 0.386 & 0.806 \\
\hline & 37,383 & $0.018^{*}$ & 0.081 & 0.324 & 0.999 \\
\hline & 37,384 & 0.147 & 0.552 & $0.021^{*}$ & 0.670 \\
\hline & 37,386 & 0.491 & 0.890 & 0.923 & 0.344 \\
\hline & 37,387 & 0.231 & 0.130 & 0.373 & 0.735 \\
\hline & 37,390 & 0.622 & 0.745 & 0.699 & 0.318 \\
\hline & 37,391 & 0.502 & 0.389 & 0.772 & 0.429 \\
\hline & 37,392 & 0.972 & 0.956 & 0.539 & 0.286 \\
\hline \multirow[t]{14}{*}{ BRN } & BISK & 0.439 & 0.638 & 0.299 & 0.250 \\
\hline & BOTA & 0.711 & 0.481 & 0.401 & 0.459 \\
\hline & FILO & 0.717 & 0.532 & 0.438 & 0.575 \\
\hline & HROZ & 0.681 & 0.619 & 0.332 & 0.448 \\
\hline & JUND & 0.917 & 0.750 & 0.159 & 0.135 \\
\hline & KRAV & 0.978 & 0.736 & 0.113 & 0.112 \\
\hline & MEND & 0.931 & 0.695 & 0.422 & 0.429 \\
\hline & $\mathrm{SCHO}$ & 0.700 & 0.574 & 0.323 & 0.389 \\
\hline & SOBE & 0.548 & 0.609 & 0.628 & 1.000 \\
\hline & STLI & 0.699 & 0.901 & 0.193 & 0.134 \\
\hline & TURA & 0.223 & 0.538 & 0.275 & 0.736 \\
\hline & VETE & 0.715 & 0.554 & 0.222 & 0.329 \\
\hline & VRAN & $0.013^{*}$ & 0.067 & 0.409 & 0.994 \\
\hline & ZIDE & 0.533 & 0.695 & 0.050 & $0.027^{*}$ \\
\hline \multirow[t]{15}{*}{ KRW } & SLOW & 0.522 & 0.086 & 0.873 & 0.880 \\
\hline & BEMA & 0.846 & 0.229 & 0.242 & 0.409 \\
\hline & BLON & 0.372 & $0.047^{*}$ & 0.789 & 0.482 \\
\hline & вOJK & 0.949 & 0.180 & 0.891 & 0.618 \\
\hline & CHOR & 0.761 & 0.348 & 0.378 & 0.431 \\
\hline & CZAJ & 0.561 & 0.088 & 0.482 & 0.292 \\
\hline & GARL & 0.347 & 0.083 & 0.054 & 0.149 \\
\hline & JEZI & 0.847 & 0.516 & 0.174 & 0.265 \\
\hline & KOCM & 0.291 & 0.317 & 0.966 & 0.446 \\
\hline & KRAS & 0.769 & 0.219 & 0.623 & 0.518 \\
\hline & LIBE & 0.275 & 0.416 & 0.876 & 0.485 \\
\hline & MALA & 0.696 & 0.155 & 0.865 & 0.533 \\
\hline & MALC & 0.325 & 0.121 & 0.070 & 0.108 \\
\hline & MODL & 0.765 & 0.393 & $0.041^{*}$ & 0.100 \\
\hline & WAND & 0.769 & 0.113 & 0.814 & 0.701 \\
\hline
\end{tabular}

(continued on next page)

\begin{tabular}{|c|c|c|c|c|c|}
\hline \multirow[t]{2}{*}{ City } & \multirow[t]{2}{*}{ m.p. } & \multicolumn{2}{|c|}{ two sample $t$-test } & \multicolumn{2}{|c|}{ two sample f-test } \\
\hline & & $2015-08-08$ & 2015-08-09 & $2015-08-08$ & 2015-08-09 \\
\hline \multirow{31}{*}{ SZE } & BOTA & 0.218 & $0.031^{*}$ & 0.644 & 0.590 \\
\hline & OJCO & 0.904 & 0.269 & 0.192 & 0.233 \\
\hline & PODW & 0.988 & 0.467 & 0.267 & 0.344 \\
\hline & SZKO & 0.310 & $0.028^{*}$ & 0.945 & 0.985 \\
\hline & PRZY & 0.454 & 0.348 & 0.811 & 0.688 \\
\hline & RZOZ & 0.752 & 0.514 & 0.373 & 0.419 \\
\hline & BALI & 0.548 & 0.202 & 0.557 & 0.630 \\
\hline & $2-1$ & 0.898 & 0.865 & 0.463 & 0.337 \\
\hline & $3-1$ & 0.911 & 0.954 & 0.327 & 0.173 \\
\hline & $5-1$ & 0.993 & 0.826 & 0.371 & 0.239 \\
\hline & $5-2$ & 0.891 & 0.627 & 0.418 & 0.497 \\
\hline & $5-3$ & 0.568 & 0.895 & 0.475 & 0.089 \\
\hline & $5-4$ & 0.998 & 0.608 & 0.355 & 0.546 \\
\hline & $6-1$ & 0.964 & 0.493 & 0.641 & 0.911 \\
\hline & $6-2$ & 0.945 & 0.545 & 0.692 & 0.890 \\
\hline & $6-3$ & 0.809 & 0.619 & 0.690 & 0.669 \\
\hline & $6-4$ & 0.970 & 0.640 & 0.587 & 0.689 \\
\hline & $6-5$ & 0.868 & 0.898 & 0.473 & 0.481 \\
\hline & $6-6$ & 0.641 & 0.677 & 0.463 & 0.467 \\
\hline & $6-7$ & 0.988 & 0.458 & 0.649 & 0.919 \\
\hline & $6-8$ & 0.786 & 0.531 & 0.697 & 0.905 \\
\hline & $6-9$ & 0.920 & 0.464 & 0.933 & 0.805 \\
\hline & $6-10$ & 0.802 & 0.644 & 0.832 & 0.887 \\
\hline & $8-1$ & 0.654 & 0.454 & 0.794 & 0.779 \\
\hline & $8-2$ & 0.983 & 0.722 & 0.523 & 0.460 \\
\hline & $9-1$ & 0.576 & 0.176 & 0.703 & 0.363 \\
\hline & $9-2$ & 0.887 & 0.206 & 0.887 & 0.480 \\
\hline & $9-3$ & 0.589 & 0.312 & 0.624 & 0.473 \\
\hline & $9-4$ & 0.562 & 0.343 & 0.322 & 0.746 \\
\hline & D-1 & 0.619 & 0.277 & 0.528 & 0.251 \\
\hline & D-2 & 0.910 & 0.523 & 0.787 & 0.524 \\
\hline \multirow[t]{9}{*}{ VIE } & 4115 & 0.509 & 0.314 & 0.091 & 0.361 \\
\hline & 5802 & 0.075 & 0.166 & 0.814 & 0.179 \\
\hline & 5805 & 0.245 & 0.135 & $0.038^{*}$ & 0.146 \\
\hline & 5904 & 0.951 & 0.581 & 0.329 & 0.817 \\
\hline & 5917 & 0.708 & 0.755 & 0.486 & 0.742 \\
\hline & 5925 & 0.497 & 0.656 & 0.786 & 0.269 \\
\hline & 5935 & 0.889 & 0.509 & 0.438 & 0.896 \\
\hline & 5972 & 0.743 & 0.519 & 0.399 & 0.770 \\
\hline & 5990 & 0.874 & 0.919 & 0.496 & 0.849 \\
\hline
\end{tabular}

Explanations: ${ }^{*} p<0.05$.

\section{References}

[1] P.J. Alexander, G. Mills, Local climate classification and Dublin's urban heat island, Atmosphere 5 (4) (2014) 755-774.

[2] I. Auer, R. Böhm, H. Mohnl, Klima von wien, in: Eine Anwendungsorientierte Klimatographie, Magistrat der Stadt Wien, 270 Seiten (=Beiträge zur Stadtforschung, Stadtentwicklung und Stadtgestaltung), Wien, 1989, p. 20.

[3] M. Baccini, A. Biggeri, G. Accetta, T. Kosatsky, K. Katsouyanni, A. Analitis, H.R. Anderson, L. Bisanti, D. D'Ippoliti, J. Danova, B. Forsberg, S. Medina, A. Paldy, D. Rabczenko, C. Schindler, P. Michelozzi, Heat effects on mortality in 15 European cities, Epidemiology 19 (5) (2008) 711-719.

[4] J.B. Basara, H.G. Basara, B.G. Illston, K.C. Crawford, The impact of the urban heat island during an intense heat wave in Oklahoma city, Adv. Meteorol. 2010 (2010) 230365 Research Article (10 pages) http://dx.doi.org/10.1155/2010/ 230365.

[5] B. Bechtel, P.J. Alexander, J. Böhner, J. Ching, O. Conrad, J. Feddema, G. Mills, L. See, I. Stewart, Mapping local climate zones for a worldwide database of the form and function of cities, ISPRS Int. J. Geoinf. 4 (1) (2015) 199-219.

[6] B. Bechtel, C. Daneke, Classification of local climate zones based on multiple earth observation data. Selected topics in applied earth observations and remote sensing, IEEE J. 5 (4) (2012) 1191-1202.

[7] P. Bénard, J. Vivoda, J. Masek, P. Smolikova, K. Yessad, C. Smith, R. Brozkova, J.F. Geleyn, Dynamical kernel of the Aladin-NH spectral limited-area model: formulation and sensitivity experiments, Quart. J. Roy. Meteor. Soc. 136A (2010) 155-169, doi:10.1002/qj.522.

[8] R. Böhm, Urban bias in temperature time series: a case study for the city of Vienna, Austria, Clim. Change 38 (1998) 113-128.

[9] A. Bokwa, Effects of air pollution on precipitation in Kraków (Cracow), Poland in the years 1971-2005, Theor. Appl. Climatol. 101 (3-4) (2010) 289-302, doi:10.1007/s00704-009-0209-7.

[10] A. Bokwa, M.J. Hajto, J.P. Walawender, M. Szymanowski, Influence of diversified relief on the urban heat island in the city of Kraków, Poland, Theor. Appl. Climatol. 122 (2015) 365-382. 
[11] COM/2013/0216, Communication from the commission to the European parliament, the Council, the European economic and social committee and the committee of the regions, An EU Strategy on adaptation to climate change (2013) pp. 11 http://eur-lex.europa.eu/legal-content/EN/TXT/?uri= CELEX:52013DC0216.

[12] P. Dobrovolný, The surface urban heat island in the city of Brno (Czech Republic) derived from land surface temperatures and selected reasons for its spatial variability, Theor. Appl. Climatol. 112 (2013) 89-98, doi:10.1007/ s00704-012-0717-8.

[13] P. Dobrovolný, L. Řezníčková, R. Brázdil, L. Krahula, P. Zahradníček, M. Hradil, M. Doleželová, M. Šálek, P. Štěpánek, J. Rožnovský, H. Valăšek, K. Kirchner, J. Kolejka, Klima Brna. Víceúrovňová Analýza Městského Klimatu [The Climate of Brno. Multilevel Analysis of Urban Climate], Masaryk Univ., Brno, 2012.

[14] B. Dong, R. Sutton, L. Shaffrey, L. Wilcox, The 2015 European heat wave [in "Explaining extremes of 2015 from a climate Perspective"], Bull. Amer. Meteor. Soc. 97 (12) (2016) S14-S18, doi:10.1175/BAMS-D-16-0149.

[15] J. Ehrhard, I.A. Khatib, C. Winkler, R. Kunz, N. Moussiopoulos, G. Ernst, The microscale model MIMO: development and assessment, J. Wind Eng. Ind. Aerod. 85 (2000) 163-176.

[16] ENVI-met: ENVI-met 3.1 Manual Contents (2009). available at: http://www envi-met.info/documents/onlinehelpv3/helpindex.htm (last access: September 2016).

[17] J. Geletič, M. Lehnert, A GIS-based delineation of local climate zones: the case of medium-sized Central European cities, Morav. Geogr. Rep. 24 (3) (2016) $2-12$.

[18] J. Geletič, M. Lehnert, P. Dobrovolný, Land surface temperature differences within local climate zones, based on two Central European cities, Remote Sens. 8 (10) (2016) 788.

[19] J. Geletič, M. Lehnert, P. Dobrovolný, Modelled spatio-temporal variability of air temperature in an urban climate and its validation: a case study of Brno, Czech Republic, Hung. Geogr. Bull. 65 (2) (2016) 169-180.

[20] J. Geletič, M. Lehnert, S. Savić, D. Milošević, Modelled spatiotemporal variability of outdoor thermal comfort in local climate zones of the city of Brno, Czech Republic, Science of the Total Environment 624 (2018) 385-395, doi:10.1016/j. scitotenv.2017.12.076.

[21] Global Climate Observing System: Austrian Inventory Report, Bundesministerium für Wissenschaft, Forschung und Wirtschaft (BMWFW), Zentralanstalt für Meteorologie und Geodynamik (ZAMG), in: Silke Adler and Hermine Fürst, ZAMG, 2017, p. 113. https://www.zamg.ac.at/cms/de/dokumente/topmenu/ gcos/gcos-report-2017. available.

[22] G. Gross, Numerical simulation of the nocturnal flow systems in the Freiburg area for different topographies, Beiträge zur Phys. Atmos. 62 (1989) 57-72.

[23] E. Gutiérrez, J.E. González, A. Martilli, R. Bornstein, M. Arend, Simulations of a heat-wave event in New York city using a multilayer urban parameterization, J. Appl. Meteorol. Climatol. 54 (2) (2015) 283-301.

[24] R. Hamdi, F. Duchêne, J. Berckmans, A. Delcloo, C. Vanpoucke, P. Termonia, Evolution of urban heat wave intensity for the Brussels capital region in the ARPEGE-Climat A1B scenario, Urban Clim. 17 (2016) 176-195.

[25] K. Hammerberg, O. Brousse, A. Martilli, A. Mahdavi, Implications of employing detailed urban canopy parameters for mesoscale climate modelling: a comparison between WUDAPT and GIS databases over Vienna, Austria, Int. J. Climatol. 38 (Suppl.1) (2018) e1241-e1257 https://doi.org/10.1002/joc.5447.

[26] J. Holec, P. Št’astný, M. Garaj, L. Burian, M. Švec, in: Creating and Processing of Local Climate Zones (LCZ) in Bratislava, 1st MUKLIMO_3 Users Workshop 2017, Vienna, Austria, 2017, pp. 9-10. 05.2017.

[27] A. Kann, C. Wittmann, C. Bica, C. Wastl, On the impact of NWP model background on very high resolution analyses in complex terrain, Wea. Forecast. 30 (2015) 1077-1089 http://dx.doi.org/10.1175/WAF-D-15-0001.1.

[28] M. Kottek, J. Grieser, C. Beck, B. Rudolf, F. Rubel, World map of the KöppenGeiger climate classification updated, Meteorol. Z. 15 (2006) 259-263, doi:10. 1127/0941-2948/2006/0130.

[29] R.S. Kovats, S. Hajat, Heat stress and public health: a critical review, Annu. Rev. Public Health 29 (2008) 41-55.

[30] H.E. Landsberg, The Urban Climate, Academic Press, New York, 1981.

[31] M. Lapin, M. Melo, Climate Change and its Possible Impacts on the Urban Areas in SW Slovakia (2011) 11-17 available at: http://www.pg.geo.uj.edu.pl/ documents/3189230/4482219/2011_126_11-17.pdf.

[32] F. Leconte, J. Bouyer, R. Claverie, M. Pétrissans, Using local climate zone scheme for UHI assessment: evaluation of the method using mobile measurements, Build. Env. 83 (2015) 39-49.

[33] M. Lehnert, J. Geletič, P. Dobrovolný, M. Jurek, Temperature differences among local climate zones established by mobile measurements in two central European cities, Clim. Res. 75 (1) (2018) 53-64.

[34] E. Lelovics, J. Unger, T. Gál, C.V. Gál, Design of an urban monitoring network based on local climate zone mapping and temperature pattern modelling, Clim. Res. 61 (1) (2014) 51-62.

[35] O. Lhotka, E. Plavcová, J. Kyselý, Record-breaking 2015 heat waves in Central Europe: how to view them in the climate change context? Geophys. Res. Abstr. 18 (2016) EGU General Assembly 2016, available at (last access 16.05.2018) http://meetingorganizer.copernicus.org/EGU2016/EGU2016-7126-1.pdf.

[36] D. Li, E. Bou-Zeid, Synergistic interactions between urban heat islands and heat waves: the impact in cities is larger than the sum of its parts, J. Appl. Meteorol. Climatol. 52 (9) (2013) 2051-2064.

[37] W.G. Meng, Y.X. Zhang, J.N. Li, W.S. Lin, G.F. Dai, H.R. Li, Application of WRF/UCM in the simulation of a heat wave event and urban heat island around Guangzhou, J. Trop. Meteorol 17 (3) (2011) 257-267.
[38] K. Mikulová, P. Št’astný, O. Bochníček, P. Borsányi, E. Čepčeková, P. Ondruška, Klimatologické normály teploty vzduchu na Slovensku za obdobie 1961-1990 NKP SR 13-I/15 Klimatologické normály za obdobie 1961-1990 na Slovensku, Slovenský hydrometeorologický ústav, 2015 ISBN 978-80-88907-92-3.

[39] I.J. Miron, C. Linares, J.C. Montero, J.J. Criado-Alvarez, J. Díaz, Changes in cause-specific mortality during heat waves in central Spain, 1975-2008, Int. J. Biometeorol. 59 (2015) 1213-1222.

[40] T.R. Oke, in: Boundary Layer Climates, Methuen, 1987, p. 289.

[41] J.A. Quanz, S. Ulrich, D. Fenner, A. Holtmann, J. Eimermacher, Micro-scale variability of air temperature within a local climate zone in Berlin, Germany, during summer, Climate 6 (1) (2018) 5.

[42] J. Resler, P. Krč, M. Belda, P. Juruš, N. Benešová, J. Lopata, O. Vlček, D. Damašková, K. Eben, P. Derbek, B. Maronga, F. Kanani-Sühring, PALMUSM v1.0: a new urban surface model integrated into the PALM large-eddy simulation model, Geosci. Model Dev. 10 (2017) 3635-3659, doi:10.5194/ gmd-10-3635-2017.

[43] A.M. Rizwan, L.Y. Dennis, L.I.U. Chunho, A review on the generation, determination and mitigation of Urban Heat Island, J. Env. Sci. 20 (1) (2008) 120-128.

[44] F. Rubel, K. Brugger, K. Haslinger, I. Auer, The climate of the European Alps: shift of very high resolution Köppen-Geiger climate zones 1800-2100, Meteorol. Z. 26 (2017) 115-125.

[45] S. Savić, V. Marković, I. Šećerov, D. Pavić, D. Arsenović, D. Milošević, D. Dolinaj I. Nagy, M. Pantelić, Heat wave risk assessment and mapping in urban areas: case study for a midsized Central European city, Novi Sad (Serbia), Nat. Hazard. 91 (3) (2018) 1-21.

[46] K.H. Schlünzen, D. Hinneburg, O. Knoth, M. Lambrecht, B. Leitl, S. López, C. Lüpkes, H. Panskus, E. Renner, M. Schatzmann, T. Schoenemeyer, S. Trepte, R. Wolke, Flow and transport in the obstacle layer: first results of the microscale model MITRAS, J. Atmos. Chem. 44 (2003) 113-130 https://doi.org/10. 1023/A:1022420130032.

[47] R. Schoetter, J. Cattiaux, H. Douville, Changes of Western European heat wave characteristics projected by the CMIP5 ensemble, Clim. Dyn. 45 (5-6) (2015) $1601-1616$.

[48] J. Siebert, U. Sievers, W. Zdunkowski, A one-dimensional simulation of the interaction between land surface processes and the atmosphere, Bound.-Layer Meteor. 59 (1992) 1-34.

[49] U. Sievers, Dreidimensionale simulationen in Stadtgebieten, in: Umwelt-meteorologie, Schriftenreihe Band 15: Sitzung des Hauptausschusses II am 7. und 8 . Juni in Lahnstein. Kommission Reinhaltung der Luft im VDI und DIN, Düsseldorf. S., 1990, pp. 92-105.

[50] U. Sievers, Verallgemeinerung der stromfunktionsmethode auf drei dimensionen, Meteorologische Zeitschrift 4 (1995) 3-15.

[51] U. Sievers, Das kleinskalige strömungsmodell MUKLIMO_3, Teil 1: Theoretische Grundlagen, PCBasisversion, Validierung. - In: Berichte des Deutschen Wetterdienstes, Band 240, Deutscher Wetterdienst, Offenbach am Main, 2012 http://nbn-resolving.de/urn:nbn:de:101:1-2014081319909.

[52] U. Sievers, (Hrsg.: deutscher Wetterdienst): das kleinskalige strömungsmodell MUKLIMO_3, Teil 2: Thermodynamische Erweiterungen. - Offenbach am Main: Selbstverlag des Deutschen Wetterdienstes. (Berichte des Deutschen Wetterdienstes; 248), 2016 ISBN: 978-3-88148-490-9 http://nbn-resolving.de/urn:nbn: de:101:1-201606173510.

[53] U. Sievers, R. Forkel, W. Zdunkowski, Transport equations for heat and moisture in the soil and their application to boundary layer problems, Beiträge Physik der Atmosphäre 56 (1983) 58-83.

[54] U. Sievers, B. Früh, A practical approach to compute short-wave irradiance interacting with subgrid-scale buildings, Meteorologische Zeitschrift 21 (2012) 349-364.

[55] U. Sievers, W. Zdunkowski, A numerical simulation scheme for the albedo of city street canyons, Boundary Layer Meteorol. 33 (1985) 245-257.

[56] N. Skarbit, I.D. Stewart, J. Unger, T. Gál, Employing an urban meteorological network to monitor air temperature conditions in the 'local climate zones' of Szeged, Hungary, Int. J. Climatol. 37 (S1) (2017) 582-596.

[57] J.-Y. Son, N. Gouveia, M.A. Bravo, C. Umbelino de Freitas, M.L. Bell, The impact of temperature on mortality in a subtropical city: effects of cold, heat, and heat waves in São Paulo, Brazil. Int J Biometeorol. 60 (2016) 113121.

[58] I.D. Stewart, T.R. Oke, Local climate zones for urban temperature studies, Bull. Am. Meteorol. Soc. 93 (2012) 1879-1900.

[59] K.E. Taylor, Summarizing multiple aspects of model performance in a single diagram, J. Geophys. Res. 106 (D7) (2001) 7183-7192 http://dx.doi.org/10.1029/ 2000JD900719.

[60] J. Unger, Intra-urban relationship between surface geometry and urban heat island: review and new approach, Clim. Res. 27 (2004) 253-264.

[61] J. Unger, S. Savic, T. Gal, Modelling of the annual mean urban heat island pattern for planning of representative urban climate station network, Adv. Meteorol. 2011 (2011) 1-9, doi:10.1155/2011/398613.

[62] J. Unger, S. Savic, T. Gal, D. Milosevic, Urban Climate and Monitoring Network System in Central European Cities, University of Novi Sad, University of Szeged, 2014.

[63] A. Urban, K. Burkart, J. Kyselý, Ch. Schuster, E. Plavcová, H. Hanzlíková, P. Štěpánek, T. Lakes, Spatial patterns of heat-related cardiovascular mortality in the Czech Republic, Int. J. Env. Res. Public Health 13 (2016) 3, doi:10.3390/ ijerph13030284.

[64] Urban population (2016). The world bank website, access: 15.03.2017 http:/ data.worldbank.org/indicator/SP.URB.TOTL.IN.ZS. 
[65] Urban population growth, in: Global Health Observatory (GHO) Data, 15, World Health Organization, access, 2015, p. 03. http://www.who.int/gho/ urban_health/situation_trends/urban_population_growth_text/en/. 2017.

[66] M.L. Verdonck, A. Okujeni, S. van der Linden, M. Demuzere, R. De Wulf, F. Van Coillie, Influence of neighbourhood information on 'Local climate Zone' mapping in heterogeneous cities, International Journal of Applied Earth Observation and Geoinformation 62 (2017) 102-113.
[67] J.P. Walawender, M. Szymanowski, M.J. Hajto, A. Bokwa, Land surface temperature patterns in the urban agglomeration of Kraków (Poland) derived from Landsat-7/ETM+ data, Pure Appl. Geophys. 171 (2014) (2014) 913-940, doi:10.1007/s00024-013-0685-7.

[68] Y. Wang, T. Haiden, A. Kann, The operational limited area modelling system at ZAMG: ALADIN-AUSTRIA, Österreichische Beiträge zu Meteorologie und Geophysik 37 (2006) 33. 